\title{
ACHIEVEMENTS OF ECONOMIC POLICY IN OVERCOMING THE EFFECTS OF THE GLOBAL ECONOMIC CRISIS ON SERBIAN ECONOMY
}

\author{
Aleksandra Prascevic* \\ Faculty of Economics, University of Belgrade, Belgrade, Serbia
}

\begin{abstract}
The paper deals with the extent to which the economic policy in Serbia has managed to respond to the economic problems imposed by the global economic crisis and how the restrictions in the form of political instability and political influence, also present before the crisis, influenced the economic policy formulated to combat the crisis. Globally, the economic crisis has resulted in the fact that, instead of the rules in economic policy making, with the key objective of maintaining price stability, now discretion and fiscal policies are being promoted, with the aim of overcoming the problem of unemployment. The significant use of discretion in the economic policy generally imposes the problem of the competence and possible political motives of economic policy makers. It is the limitations of underdeveloped institutions and a wrong model of growth that have contributed to the fact that the results of the economic policy in Serbia have not been significant. Serbia is facing the negative consequences of the measures implemented in the form of high budget deficits, public debt and inflation, while the effects on the economic activity and employment have failed, causing the present choice between rules and discretion.
\end{abstract}

Keywords: global economic crisis, economic policy, political macroeconomics

JEL Classification: E60, E62

\section{INTRODUCTION}

The global economic crisis (2007-09) launched by the financial crisis and economic recession in the United States, officially in December 2007, as a single economic event that cannot be subsumed under the standard cyclical downturn in the economic activity has led to significant changes in the objectives and instruments

* Correspondence to: A. Prascevic, Faculty of Economics, University of Belgrade, Kamenicka 6, 11000 Belgrade, Serbia; e-mail: alja@ekof.bg.ac.rs of the economic policy (Prascevic, 2012, 626). After a decade of the domination of rules in economic policy making and the primary objective of price stability by relying on the monetary policy, the need for mitigation and an as-fast-as-possible recovery from the economic crisis imposed discretion in economic policy making, especially in terms of fiscal policy (Spilimbergo et al, 2008). Unemployment also became a key economic issue, which is why the economic policy and the fiscal policy in particular turned towards overcoming this problem. 
These changes in the objectives and the economic policy instruments used imposed the question of whether this is a definite change in the domain of macroeconomic theory (abandoning the neoliberal paradigm), i.e. whether this is a fundamental change of the economic policy (the abandonment of rules and return of discretion), or whether this is a shortterm return of Keynesianism. In the years after the global economic crisis, marked by a slow recovery and problems of public finance in almost all the countries affected by the crisis, the effects of the measures taken to overcome the crisis are being considered. The aim of this paper is to determine the effects of the economic policy measures on overcoming the negative impact of the global economic crisis (2007-2009) in Serbia. The paper discusses the key elements of the measures taken, primarily of the fiscal stimulus, but also the impact of the monetary policy. The effects of the measures of the economic policy are herein discussed in light of the fact that they were preceded by a period of an extraordinary fiscal expansion, which was primarily politically motivated - by political instability and the model of growth based on domestic demand. The paper examines the hypothesis that the economic policy implemented in order to overcome the economic crisis was partly motivated by a real need to improve the economic activity, but also that partially it resumed the previously politically-generated stimulation, based on a combination of opportunistic and partisan motives. The previous abuses of the economic policy in Serbia have considerably limited the possibility of using the economic policy to overcome the economic crisis.

The paper uses relevant data - macroeconomic indicators in Serbia for the analysed period, and applies the key premises of the developed models of the political cycles - opportunistic and partisan (Nordhaus 1975; Hibbs, 1977; Rogoff, 1990; Rogoff \& Sibert, 1988; Alesina, 1987). After the introduction, the paper comprises the following parts: The Effects of the Global Economic Crisis on the Serbian Economy, Fiscal Policy - the Way to Overcome the Recessionary Pressures or the Source of Political Manipulations, Economic Policy in the Pre-electoral Period and the New Economic Policy, and the Conclusion.

\section{THE EFFECTS OF THE GLOBAL ECONOMIC CRISIS ON THE SERBIAN ECONOMY}

The global economic crisis has significantly affected the economy of Serbia. The slowdown of the global economy, the problems of the financial sector and the functioning of the financial system, which have considerably impaired global lending and reduced liquidity, have also had a negative effect on the economies of emerging markets and the transitional economies, including the Serbian economy. These effects have related both to the problem of reduced global aggregate demand, which has resulted both in a slowdown in the economic activity and exports, and a reduction in the capital inflows in the form of investment and growth in the cost of borrowing due to the reduced global liquidity.

The start of the crisis spillover in Serbia took place in the last quarter of 2008, and was first marked by the fear from a significant impact on the banking sector, due to the frequent bankruptcies of financial institutions in the world. However, apart from a short-term effect on the withdrawal of foreign savings from the banks in Serbia (in October 2008, about 1 billion euros were withdrawn), significant effects were prevented and the banking sector remained stable, while the measures by which the state guaranteed for deposits led to the stabilization and return of savings to the banks.

The strongest impact of the crisis on the economy of Serbia was recorded in 2009 when, for the first time since the political changes in 2000, the GDP recorded a decline (Table 1). A significant slowdown in the economic activity was recorded in the second half of the year 2008, as a result of the decline in aggregate demand in both its components - domestic and export demand. The decline in domestic demand had a more significant effect, although it was smaller than the decline in export demand; however, due to a significant share in the total demand, its decline had a significant impact on the economic activity slowdown. (Prascevic, 2012b, 144)

All macro indicators in 2009 show adverse economic trends. Although it is certain that the effect of the global economic crisis was decisive for them, it is still important to note that the errors in economic policy 
making in the period before the year 2008 also had its share in such poor indicators (Stamenkovic et al, 2009, 24). This specifically refers to the two internal factors:

- the choice of the economic growth model based on aggregate demand, domestic demand, to be more precise,
- political instability and economic policy making in the coalition government environments,

These factors are interrelated and interdependent. First, the choice of the growth model that generated the insufficiently dynamic development of both internal and external imbalances had a foothold in the political factors that dominated the period after

Table 1 Key macroeconomic indicators in Serbia (2002-2012)

\begin{tabular}{|c|c|c|c|c|c|c|c|c|c|c|c|c|c|c|}
\hline & 2002 & 2003 & 2004 & 2005 & 2006 & 2007 & 2008 & 2009 & 2010 & 2011 & $\begin{array}{c}\text { Q1 } \\
2012\end{array}$ & $\begin{array}{c}\text { Q2 } \\
2012\end{array}$ & $\begin{array}{c}\text { Q3 } \\
2012\end{array}$ & $\begin{array}{c}\text { Q4 } \\
2012\end{array}$ \\
\hline $\begin{array}{l}\text { Real growth of GDP } \\
\text { (in \%) }\end{array}$ & $4 \cdot 3$ & 2.5 & 9.3 & $5 \cdot 4$ & 3.6 & 5.4 & 3.8 & -3.5 & 1.0 & 1.6 & -2.3 & -0.6 & -2.5 & -1.5 \\
\hline $\begin{array}{l}\text { Consumer prices (in } \\
\% \text {, year-on year) }\end{array}$ & 14.8 & 7.8 & 13.7 & 17.7 & 6.6 & 11.0 & 8.6 & 6.6 & 10.3 & 7.0 & 3.2 & 5.5 & 10.3 & 12.2 \\
\hline $\begin{array}{l}\text { NBS foreign cur- } \\
\text { rency reserve (in } \\
\text { million EUR) }\end{array}$ & 2,186 & 2,836 & 3,104 & 4,921 & 9,020 & 9,634 & 8,162 & 10,602 & 10,002 & 12,058 & 11,073 & 10,161 & 9,833 & 10,914 \\
\hline $\begin{array}{l}\text { Export (in million } \\
\text { EUR) }\end{array}$ & 3,125 & 3,847 & 4,475 & 5,330 & 6,949 & 8,686 & 10,157 & 8,478 & 10,070 & 11,486 & 2,519 & 3,031 & 3,083 & $3.293,6$ \\
\hline $\begin{array}{l}\text { - growth rate in \% } \\
\text { year-on-year }\end{array}$ & 16.0 & 23.1 & 16.3 & 19.1 & 30.4 & 25.0 & 16.9 & -16.5 & 18.8 & 14.1 & -2.6 & 5.2 & 3.2 & 8,7 \\
\hline $\begin{array}{l}\text { Import (in million } \\
\text { EUR) }\end{array}$ & $-6,387$ & $-7,206$ & $-9,543$ & $-9,613$ & $-11,971$ & $-16,016$ & $-18,843$ & $-13,404$ & $-14,643$ & $-16,627$ & $-4,042$ & $-4,323$ & $-4,235$ & $-4.620,7$ \\
\hline $\begin{array}{l}\text { - growth rate in \% } \\
\text { year-on-year }\end{array}$ & 27.2 & 12.8 & 32.4 & 0.7 & 24.5 & 33.8 & 17.7 & -28.9 & 9.2 & 13.6 & 5.5 & 6.3 & 1.3 & 1,6 \\
\hline \multicolumn{15}{|l|}{$\begin{array}{l}\text { Current account } \\
\text { balance }\end{array}$} \\
\hline in million EUR & -671 & $-1,347$ & $-2,620$ & $-1,778$ & $-2,356$ & $-5,053$ & $-7,054$ & $-1,910$ & $-1,887$ & $-2,856$ & $-1,177$ & -738 & -546 & $-685,8$ \\
\hline as \% of GDP & -4.2 & -7.8 & -13.8 & -8.8 & -10.1 & -17.7 & -21.6 & -6.6 & -6.7 & -9.2 & -16.9 & -10.2 & -7.3 & $-8,3$ \\
\hline $\begin{array}{l}\text { Unemployment } \\
\text { according to Survey } \\
\text { (in \%) }\end{array}$ & 13.3 & 14.6 & 18.5 & 20.8 & 20.9 & 18.1 & 13.6 & 16.1 & 19.2 & 23.0 & 1 & 25.5 & 1 & 22.4 \\
\hline $\begin{array}{l}\text { Wages (average for } \\
\text { the period, in EUR) }\end{array}$ & 152.1 & 176.9 & 194.6 & 210.4 & 259.5 & 347.6 & 402.42 & 337.9 & 330.1 & 372.5 & 357.6 & 363.2 & 351.8 & 385.3 \\
\hline $\begin{array}{l}\text { RS budget deficit/ } \\
\text { surplus (\% of GDP) }\end{array}$ & -4.3 & -2.6 & -0.3 & 0.3 & -1.9 & -1.7 & -1.7 & -3.4 & -3.7 & -4.2 & -7.0 & -7.1 & -3.9 & -5.0 \\
\hline $\begin{array}{l}\text { Consolidated fiscal } \\
\text { result (\% of GDP) }\end{array}$ & -1.8 & -2.4 & 0.8 & 0.9 & -1.9 & -2.0 & -2.6 & -4.5 & -4.7 & -5.0 & -7.3 & -6.9 & -4.1 & $-7 \cdot 3$ \\
\hline $\begin{array}{l}\text { RS's public debt, } \\
\text { (external + internal, } \\
\% \text { of GDP) }\end{array}$ & 72.9 & 66.9 & 55.3 & 52.2 & 37.7 & 31.5 & 29.2 & 34.7 & 44.5 & 48.7 & 52.0 & 56.0 & 55.1 & 59.2 \\
\hline $\begin{array}{l}\text { RSD/EUR foreign } \\
\text { exchange (average } \\
\text { for the period) }\end{array}$ & 60.66 & 65.13 & 72.70 & 83.00 & 84.10 & 79.96 & 81.44 & 93.95 & 103.04 & 101.95 & 108.11 & 113.73 & 116.95 & 113.45 \\
\hline $\begin{array}{l}\text { RSD/EUR foreign } \\
\text { exchange (end of } \\
\text { period) }\end{array}$ & 61.52 & 68.31 & 78.89 & 85.50 & 79.00 & 79.24 & 88.60 & 95.89 & 105.50 & 104.64 & 111.36 & 115.82 & 115.03 & 113.72 \\
\hline
\end{tabular}

Source: Narodna banka Srbije. Statistika - Osnovni makroekonomski indikatori. 
the democratic changes in 2000, which can simply be defined as political instability. Although in the literature it is defined in various ways and comprises different elements (Prascevic, 2008a, 259-261), in Serbia, in the period of 2000-2008, political instability can be identified with frequent elections at different levels (Prascevic, 2008b, 50) and significant political differences between the political parties, especially between the coalition partners in the government. Therefore, in addition to frequent elections, there were also very strong tensions within the government, which often resulted from political issues (the pace of the political reforms required for the EU accession) and economic issues as well. Among the most important ones were: the disagreements within the government (2003-2007), which started in May 2006, due to a freeze of the negotiations on the Stabilization and Association Agreement with the EU for political reasons, which ended in 2007, by calling the regular elections in November 2006 for January 2007 (the preelectoral campaign lasted since May 2006, which is precisely the period in which the changes occurred in the form of an extreme expansionary fiscal policy), the differences within the coalition government (2007-2008) which occurred as soon as in late 2007, which ended in elections in 2008 (the entire 2007 was characterized by a significant fiscal expansion), the disagreements within the coalition government (20082012), which were primarily related to economic issues in February 2011, which did not result in the collapse of the government, but did result in the reconstruction of the government, as well as long-term consequences in the form of the alienation of the formerly crucial coalition partners.

For the key episodes of the economic policy in Serbia, the macroeconomic policy premises on the possible abuse of the economic policy by its creators were prominent in both its forms - the opportunistic and the partisan motives (Jaksic \& Prascevic, 2010, 17-18). For the realization of its opportunistic objectives, the Serbian political elite received support from the Serbian economic elite, at least from one of its parts, which affected both the growth model, and the concrete of economic policy measures as well, but also the most destructive thing - the choice of almost completely dysfunctional institutions. This choice has had longterm negative effects on economic developments.

Frequent elections were one of the key reasons for the slowdown of reforms, given that from one election to the next, the support for a rapid and radical reform decreased. The political elite (the pro-reform and proEuropean one) opted for a more significant "purchase" of voters, precisely in the form of an increase in the purchasing power and the standard of living, above the possibilities dictated by the economic growth (Prascevic, 2010, 94). The growth in domestic demand was primarily funded through the capital inflows from abroad, from privatization, which meant a onetime influx of funds. The growth reached its downfall with the onset of the global economic crisis when the errors of the economic policy started to come to light, worsening the already bad economic situation.

The indicators of real private consumption in Serbia point to its prominent participation in the GDP (as much as above $90 \%$ ), which is more than in all other countries, and significantly above the average for the EU27 countries (Radisavljevic, 2010, 28). This level of real personal consumption represents a significant constraint to economic growth. However, when we consider the actual height of the real per capita private consumption and compare it with the other countries of the Western Balkans and the EU, it can be seen that, in the period 2005-09, it reached 38 to $45 \%$ of the EU27 average, while in the same period, the GDP index was 32 to $37 \%$ of the average achieved in the EU27 (Radisavljevic, 2010, 32). Therefore, the growth of real personal consumption was faster than the growth of the GDP, but by the amount of its real personal consumption per capita, Serbia can be classified into and compared with the Western Balkans countries.

Even before the global crisis, the economy of Serbia was faced with a significant problem with the external imbalance and fiscal deficits. However, even such a small volume of exports registered a year-on year decline of $16.5 \%$ in 2009 . At the same time, due to the fall in domestic demand, as well as the production, there was a significant year-on-year drop in imports by as much as $28.9 \%$. It caused the improvement of the current account deficit, which amounted to $6.6 \%$ of the GDP, compared to $21.6 \%$ of the GDP in 2008 (Table 2), as a consequence of reducing the total foreign trade 
Table 2 Serbia's Balance of Payments (2007-2011)

\begin{tabular}{|c|c|c|c|c|c|c|}
\hline \multicolumn{2}{|c|}{ POSITIONS } & 2007. & 2008. & 2009. & 2010. & 2011. \\
\hline \multicolumn{2}{|c|}{ I. CURRENT ACCOUNT } & $-5,052.5$ & $-7,054.2$ & $-1,910.1$ & $-1,887.2$ & $-2,776.0$ \\
\hline \multicolumn{2}{|r|}{ CURRENT ACCOUNT WITHOUT OFFICIAL AID } & $-5,218.9$ & $-7,216.8$ & $-2,107.6$ & $-2,080.3$ & $-2,976.1$ \\
\hline \multicolumn{2}{|r|}{ 1. Coods (1.1-1.2.) } & $-7,068.7$ & $-8,501.2$ & $-4,946.4$ & $-4,581.0$ & $-5,318.4$ \\
\hline \multicolumn{2}{|r|}{ 1.1. Source of goods, f.o.b. } & $6,382.5$ & $7,416.0$ & $5,977.8$ & $7,402.5$ & $8,439.7$ \\
\hline \multicolumn{2}{|r|}{ 1.2. Import of goods, f.o.b } & $-13,451 \cdot 3$ & $-15,917.2$ & $-10,924.2$ & $-11,983.6$ & $-13,758.1$ \\
\hline \multicolumn{2}{|r|}{ 2. Services (2.1.-2.2.) } & -261.1 & -184.7 & 20.5 & 7.7 & 163.2 \\
\hline \multicolumn{2}{|r|}{ 2.1. Revenues } & $2,304.0$ & $2,741.4$ & $2,500.0$ & $2,667.1$ & $3,032.3$ \\
\hline \multicolumn{2}{|r|}{ 2.2. Expenditures } & $-2,565.1$ & $-2,926.1$ & $-2,479.5$ & $-2,659 \cdot 4$ & $-2,869.1$ \\
\hline \multirow[t]{3}{*}{3.} & Balance of goods and services (3.1.-3.2.) & $-7,329.9$ & $-8,685.9$ & $-4,925.8$ & $-4,573.3$ & $-5,155 \cdot 2$ \\
\hline & 3.1. Export of goods and services & $8,686.5$ & $10,157 \cdot 3$ & $8,477.8$ & $10,069.6$ & $11,472.0$ \\
\hline & 3.2. Import of goods and services & $-16,016.4$ & $-18,843.2$ & $-13,403.6$ & $-14,642.9$ & $-16,627.2$ \\
\hline \multirow[t]{3}{*}{4.} & Income & -598.7 & -921.8 & -502.5 & -669.9 & -757.9 \\
\hline & 4.1. Revenues & 516.9 & 558.1 & 499.7 & 437.7 & 428.2 \\
\hline & 4.2. Expenditures & $-1,115.6$ & $-1,479.9$ & $-1,002.1$ & $-1,107 \cdot 5$ & $-1,186.2$ \\
\hline \multirow[t]{3}{*}{5.} & Current transfers & $2,876.1$ & $2,553.6$ & $3,518.2$ & $3,356.0$ & 3,137.1 \\
\hline & 5.1. Revenues & $3,104 \cdot 7$ & $2,828.3$ & $3,762.0$ & $3,624.0$ & $3,488.2$ \\
\hline & 5.2. Expenditures & -228.6 & -274.7 & -243.8 & -268.0 & -351.0 \\
\hline \multicolumn{2}{|c|}{ II. CAPITAL ACCOUNT } & -313.9 & 13.2 & 1.6 & 0.9 & -2.5 \\
\hline \multicolumn{2}{|c|}{ III. FINANCIAL ACCOUNT } & $5,175.6$ & $7,133 \cdot 3$ & $2,032.6$ & $1,818.5$ & $2,609.2$ \\
\hline \multicolumn{2}{|c|}{ 1. Direct investment - net } & $1,820.8$ & $1,824 \cdot 4$ & $1,372.5$ & 860.1 & $1,826.9$ \\
\hline \multicolumn{2}{|r|}{ 2. Portfolio investment - net } & 678.2 & -90.9 & -51.0 & 38.8 & $1,619.1$ \\
\hline \multicolumn{2}{|r|}{ 3. Other investment } & $3,418.7$ & $3,713.2$ & $3,074.6$ & -9.1 & 964.6 \\
\hline \multicolumn{2}{|r|}{ 3.1. Assets (receivables) } & $-1,618.3$ & $-1,451.1$ & 75.3 & -791.9 & $455 \cdot 4$ \\
\hline \multicolumn{2}{|r|}{ 3.1.1. Trade loans } & -860.0 & -601.5 & -394.7 & -368.9 & -300.2 \\
\hline \multicolumn{2}{|r|}{ 3.1.2. Financial loans } & 1.1 & -30.5 & 24.8 & -34.0 & -18.4 \\
\hline \multicolumn{2}{|r|}{ 3.1.3. Cash and deposits } & -710.3 & -787.9 & 445.2 & -389.0 & 774.0 \\
\hline \multicolumn{2}{|r|}{ 3.1.4. Other assets } & -49.1 & -31.2 & & & \\
\hline \multicolumn{2}{|r|}{ 3.2. Equity (liabilities) } & $5,037.0$ & $5,164 \cdot 3$ & $2,999.2$ & 782.8 & 509.2 \\
\hline & 3.2.1. Trade loans & $1,619.2$ & $1,558.6$ & 873.9 & 284.6 & 808.3 \\
\hline & 3.2.2. Financial loans & $3,402.1$ & $3,529.2$ & $1,388.7$ & 863.5 & -394.6 \\
\hline & 3.2.2.1. NBS & -91.5 & 0.0 & $1,114 \cdot 4$ & 341.0 & 44.8 \\
\hline & 3.2.2.2. Government & 121.1 & 98.4 & 258.2 & 735.3 & 687.5 \\
\hline & 3.2.2.2.1. Long-term & 121.1 & 116.3 & 256.7 & 736.8 & 687.5 \\
\hline & 3.2.2.2.2. Short-term & & -17.9 & 1.5 & -1.5 & \\
\hline & 3.2.2.3. Banks & 166.6 & 155.4 & 869.1 & 659.7 & -710.8 \\
\hline & 3.2.2.3.1. Long-term & -126.3 & -260.2 & 474.2 & 651.9 & 437.8 \\
\hline & 3.2.2.3.2. Short-term & 292.9 & 415.6 & 394.9 & 7.8 & $-1,148.5$ \\
\hline & 3.2.2.4. Other sectors & $3,205.9$ & $3,275 \cdot 3$ & -853.0 & -872.4 & -416.1 \\
\hline & 3.2.3. Cash and Deposits & 68.8 & 75.3 & 314.5 & -365.3 & 95.6 \\
\hline & 3.2.4. Other equity & -53.1 & 1.2 & & & \\
\hline & 3.2.5. SDR allocation & & & 422.2 & & \\
\hline 4. & Reservesi & -742.1 & $1,686.6$ & $-2,363.5$ & 928.7 & $-1,801.5$ \\
\hline IV EF & RRORS AND OMISSIONS-net & 190.8 & -92.3 & -124.1 & 67.8 & 169.3 \\
\hline & OTAL BALANCE & 742.1 & $-1,686.6$ & $2,363.5$ & -928.7 & $1,801.5$ \\
\hline
\end{tabular}

Source: Narodna banka Srbije. Statistika - Platni bilans RS. 
of Serbia. At the end of 2009, the economic activity recovered, and again, there was a tendency of a faster growth in imports than it was in exports (an average of $6 \%$ versus $4 \%$ ), which caused an increase in the current account deficit as well as in the trade deficit in goods.

During the period of the strongest impact of the crisis on the economy of Serbia in 2009, the financial account surplus decreased as compared to 2008. This was also partially caused by a fall in net foreign direct investment (from 1.824 million to 1.372 million euro), the portfolio investment deficit was reduced from 91 million to 51 million, and a decline was recorded in other investments as well (from 3,713 to 3,075 million euros). Within this position, there were significant financial loans taken by the banking sector (shortterm), as well as the IMF loan disbursement for the state (from SBA 1,114 million euros and 422 million euros in Special Drawing Rights), but also the influx of cash and deposits (Table 2). At the same time, in 2009, there was an increase in foreign exchange reserves amounting to 2,363.5 million euros (contributed to by the funds received from the IMF, amounting to 1.54 bln. euros and 400 million euros from the sale of NIS), in contrast to the decline of the reserve in 2008 by 1,686.6 million.

During the recessional 2009, the inflation rate was declining (the annual total $6.6 \%$, compared to 2008, when it was $8.6 \%$ ), which corresponds to theoretical explanations, i.e. could be considered as the consequence of the decline in domestic demand (due to a wage freeze in the public sector and the growth of unemployment - layoffs in the private sector), as well as an increased uncertainty. During the period of the main effects of the global crisis, the exchange rate depreciated against the euro - the nominal depreciation by about 6\% (February 2010 compared to September 2009), the real depreciation at the end of 2009 compared to September 2008 was about 14\%.

As early as in late 2008, the monetary policy was directed at limiting the rapid depreciations of the dinar through the restrictive monetary policy and, at first, by raising the interest rates. This measure was also expected to have an effect on limiting inflation, whose trends at the beginning of the spillover of the crisis, in late 2008 and early 2009, were still worrying, although the rate of inflation stabilized by the end of 2009 , only to become topical again with the recovery in 2010, which is consistent with the fact that the inflation rate is a lagging indicator. The depreciation of the dinar was stimulating for the economic activity, primarily in encouraging exports and restricting imports, but because of the fear of inflation, it was insisted on a limited depreciation involving monetary contraction.

In addition to preventing a more significant depreciation of the exchange rate, the monetary authorities were faced with the problem of reduced liquidity in the economy. However, this problem was not primarily addressed by the NBS because of the inflationary pressures and the inability to decrease the interest rate, but it was rather left to the fiscal policy. The monetary policy was not used for countercyclical purposes, but primarily for the maintenance of macroeconomic stability - price stability and to reduce the exchange rate fluctuations. Such a choice of the monetary authorities was not surprising if we take into account the fiscal constraints and other factors related to the previous character of the economic growth in Serbia. The monetary response was largely conditioned by the fiscal imbalance and the inability to address the fiscal imbalances that had existed in Serbia even before the crisis, which had political origins. Therefore, the monetary policy remained the guarantor of macroeconomic stability, which led to the conclusion on an insufficient coordination between the monetary and fiscal policies, which were implemented to overcome the effects of the global economic crisis.

\section{FISCAL POLICY - THE WAY TO OVERCOME THE RECESSIONARY PRESSURES OR THE SOURCE OF POLITICAL MANIPULATIONS}

Serbia entered the period of the global economic crisis with an open problem of public finances the state budget deficit, which was the result of an expansionary fiscal policy in the period of 2006-2008, exactly coinciding with the politically motivated abuses of the economic policy and the slowdown of the economic reforms. The shifts in fiscal policy making precisely coincide with the election cycles realised in 
the period before the onset of the crisis in Serbia. The especially important years (in the context of the preelectoral expansionary fiscal policy) are the years 2006, 2007 , and 2008, i.e., the three years immediately before the onset of the global economic crisis.

From the budget surplus of around 1\% of the GDP achieved in 2005, the economy shifted to a deficit of around $2 \%$ of the GDP (2006, and 2007), or $2.6 \%$ of the GDP (2008). The first effects of the global economic crisis started in such unfavourable conditions when it was legitimate to assume that there would be a drop in the GDP, which, if the measures of the fiscal austerity or tax increase were not taken, would lead to an even greater deficit of the state budget. At the same time, it could be assumed that the restrictive fiscal policy would be difficult to implement in a time of crisis when the decline in tax revenues due to the economic downturn is inevitable, while an even greater pressure to increase budget expenditures in order to stimulate the economic activity of the state could be anticipated, through various forms of stimulations for the economy and consumers. The increased budget expenditures were aggravated by to the deterioration of the social status of the population and the inevitable growth of unemployment. Therefore, the deficit situation worsened, so that during the crisis year of 2009, the consolidated budget deficit amounted to $4.5 \%$ of the GDP, and due to the extraordinarily expansionary fiscal policy and the lack of economic recovery, it remained quite high even in the post-crisis years $(4.7 \%$ in 2010, and 5.0\% in 2011). In the last year 2012, which was also the election year and the year of the change of the government (the policy makers), the problem of the deficit culminated, the deficit being as high as $7.3 \%$ of the GDP in the last quarter (Table 1), imposing itself as the first and the most important issue for the economic policy makers.

In the domain of the political abuse of the fiscal policy for political purposes - electoral purposes (the budget political cycles), political macroeconomics distinguishes several forms, which were the basis for the development of the appropriate budget cycle models (Cukierman \& Meltzer, 1986; Rogoff \& Sibert, 1988; Rogoff, 1990; Drazen, 2000). Among them are: the models based on a fiscal illusion, the models in which the budget deficit is a strategic variable, the intergenerational redistribution models, the distribution conflict models, the geographically dispersed interest models, and the models of budgetary institutions (Jaksic \& Prascevic, 2010, 279-290). The key mechanisms of the fiscal abuses discussed in these models can be applied to the fiscal policy in Serbia before, during and after the global economic crisis.

The models based on fiscal illusion imply that voters are characterized by "fiscal illusion", or that they do not understand the intertemporal budget constraint - overestimating the benefits of the current increase in expenditure and underestimating the current and future tax liabilities. Therefore, voters do not punish the opportunistically motivated policy of generating budget deficits. In Serbia, this form of fiscal illusion was supplemented by another factor - privatization revenues that could be used for opportunistic political purposes as well. One such example was the National Investment Plan - NIP (2006-2011), which defined a number of priorities in the fields of infrastructure, regional development, as well as education, health and culture. Instead of a carefully devised and planned state investment in the four sectors, which in the medium term would lead to the growth of productive potentials of the country, and thus future budget revenues, these effects did not materialise.

The fiscal policy in Serbia in the pre-electoral period fits with the models of rational budget cycles, which implies that voters are fiscally conservative and deceived by changes in the structure of the government expenditures in favour of those that are quick and easily "visible". Thus, in election years, a significant increase in the so-called discretionary public spending - public investment, subsidies, lending, etc. can be observed. These expenditures provide "competence" for monetary policy makers, which misleads the voters.

The fiscal policy measures with significant political stronghold in the period before the economic crisis (2006-2008) were the following:

- a marked increase in the salaries in the public sector during the electoral year 2006, which continued in 2007 , based on the realization of the agreements between the trade unions and the government in the pre-election period in 2006; 
- the launch of the National Investment Plan in 2006;

- the subsidy programs for enterprises (small, medium and those that were being restructured) in 2006;

- a reduction in the income tax and the introduction of non-taxable earnings in 2007, and

- a reduction in some tax rates - tax on transfer, VAT for certain products, total exemption from payment of VAT for first-time home buyers in 2007 (Prascevic, 2012b, 147)

This behaviour of the fiscal authorities in the precrisis period limited the possibility of its being used in stimulating the economic activity in Serbia during the crisis. The May 2009 revised agreement with the IMF increased the allowed deficit to $4.5 \%$ of the GDP, which was in line with the changes in the approach of the IMF due to a drastic economic contraction, but it was also an expression of the reality preventing the implementation of more significant austerity measures as they would contribute to greater recession.

Despite the limitations imposed by the past trends due to which, immediately after the formation of the previous government (in July 2008), a need for fiscal consolidation emerged, it is possible to observe the continuation of the politically motivated fiscal and broader economic policies to fight the recession, led by the government (2008-2012). The objective reason for this can be found in the fact that the previous government, at least initially, called itself "socially responsible government", whose key objectives, in addition to joining the EU, were a faster economic growth, a lower unemployment rate and an improvement of the living standards, the reduction of poverty and a more equitable distribution of the costs of the economic reforms and transition. The factors relating to the composition of the coalition government which brought together political parties of different orientations (with different economic objectives), as well as the coalition agreement on the functioning of the government (the division of the ministerial portfolios amongst the coalition partners) and the ruling majority, the management of public enterprises and the like, significantly aggravated the implementation of fiscal stabilization. Very soon, there was a problem known in the models of political macroeconomics as the distributional conflict, when the coalition partners in the government, who formulate fiscal policy, do not want to transfer the burden of fiscal stabilization to themselves or their constituents, but rather try to transfer that burden to other coalition partners (Alesina \& Drazen, 1991, 1170).

The antirecession measures taken by the state (a support for the financial sector, deposit insurance, subsidized interest rates for certain loans, the provision of loans to small and medium-sized enterprises, encouraging public investment) had positive effects (Prascevic, 2012b, 152), although during 2009, there was also a pronounced effect of squeezing out as a consequence of the high state budget deficit, on the one hand, and large credit risks to the economy, on the other, which is the reason why banks preferred investing in the government bonds to investing in the economy. It was further emphasised by the fact that the fiscal deficit in Serbia in 2009 was financed primarily by borrowing, as the sources of privatization revenues had dried up. An important support to the economic policy in 2009 was an arrangement with the IMF encompassing the financial support of EUR 2.9 billion. The program stipulated a reduction of public and private sector consumption, since it could no longer count on the substantial inflows of foreign capital. The Program stipulated freezing the public sector wages and pensions, which remained valid during 2010 as well, and reduced discretionary spending on goods and services, subsidies, loans to all levels of the government. However, public expenditure recorded the highest decrease in capital expenditures, which indicated significant recessionary trends.

The year 2010 noted a weak recovery (the GDP growth of $1.0 \%$ ), which continued in 2011 (the GDP growth of $1.6 \%$ ), which was significantly lower than the rates that had existed before the crisis. During 2010, there was a recovery in aggregate demand and a significant growth in export demand, which can simply be explained by the fact that wages and pensions remained frozen, and the problem of high unemployment rates became topical again, which is the reason why a significant increase in domestic demand was not possible. The trends in the labour market in the post-crisis period (2010, 2011, and 2012) were not encouraging though (unemployment continued to rise and employment 
continued to decline - Table 3). It should also be stated that the number of persons who have lost their jobs does not apply to the public sector, because precisely due to the effects of the global economic crisis and negative economic developments in the country, the needed public sector reform that will inevitably involve layoffs in the sector and the growth of unemployment in this respect has been postponed. Still, the trends in the labour market have been extremely unfavourable - in four years (since 2008), the employment rate dropped by about $10 \%$, which makes the situation in Serbia even more complicated and reflects a harsh economic situation for the majority of the population in Serbia.

Table 3 Employment and unemployment rates in Serbia, 2004-2012

\begin{tabular}{lccc}
\hline & $\begin{array}{c}\text { Employ- } \\
\text { ment rate } \\
\text { (age 15-64) }\end{array}$ & $\begin{array}{c}\text { Total number of } \\
\text { the employed } \\
\text { (age 15-64) }\end{array}$ & $\begin{array}{c}\text { Unemploy- } \\
\text { ment rate } \\
\text { (age 15-64) }\end{array}$ \\
\hline Oct. 2004 & 53,4 & 2.735 .977 & 19,5 \\
Oct. 2005 & 51,0 & 2.574 .139 & 21,8 \\
Oct. 2006 & 49,8 & 2.516 .794 & 21,6 \\
Oct. 2007 & 51,5 & 2.525 .570 & 18,8 \\
Oct. 2008 & 53,3 & 2.646 .215 & 14,7 \\
Oct. 2009 & 50,0 & 2.450 .643 & 17,4 \\
Oct. 2010 & 47,1 & 2.269 .565 & 20,0 \\
Oct. 2011 & 45,3 & 2.141 .920 & 24,4 \\
Oct. 2012 & 44,2 & 2.083 .604 & 26,1 \\
\hline
\end{tabular}

Source: Republički zavod za statistuku. Anketa o radnoj snazi.

The recovery of the Serbian economy was very weak, and the issues related to the rising inflation, the budget deficit and the public debt became more prominent, so that in some periods, the monetary policy opted for marked tightening in curbing inflation. The exchange rate recorded significant fluctuations that, on the one hand, indicated a need for a further depreciation of the dinar, whereas on the other, the demands and to shift to a fixed exchange rate become increasingly more prominent, which would have been particularly difficult to implement in a situation of very unfavourable fiscal flows that were active in Serbia in the past several years.

The fiscal trends in Serbia show that the governments in unstable and polarized political systems, such as those in Serbia, are prone to high deficits, because the deficit is positively correlated with the degree of the political polarization potential between potential governments, the tenure of the government and the prospect that the government is not re-elected (Persson \& Svensson, 1989; Alesina \& Tabellini, 1990). The undisputed political polarization in Serbia has led to a situation where the budget deficit has become a strategic variable, which the current government uses to affect the fiscal policy of the future government, as the manipulation of the current fiscal policy affects the choice of a fiscal policy to be implemented by future policy makers, although they may have different preferences. An example of such a fiscal policy is the policy before and after the last elections (parliamentary and presidential, in May 2012).

\section{ECONOMIC POLICY IN THE PRE- ELECTORAL PERIOD AND THE NEW ECONOMIC POLICY}

Political instability in the country has intensified since mid-2011 (more significant differences between the coalition partners in the government and the pressure from the opposition parties to call early elections) significantly affected the economic trends, too. These tensions ended in the regular parliamentary (state and local) and early presidential elections, held in early May 2012. This is why the first half of the year 2012 was characterised by pre-electoral activities, and due to the change of the government at the national level (the government and the president of the Republic) and at the local levels, the second half of the year was largely devoted to the formation and consolidation of power, and the economic policy makers announced significant changes with respect to the preceding economic policy. Taking into account past experiences with economic trends in the pre-election and postelection periods in Serbia, it is not surprising that in 2012, they were very unfavourable. It should be added 
that the economic trends at the global level, and those in the euro area are particularly important to Serbia, became unfavourable as well (the euro are went back into recession again).

The fiscal policy had an especially important role, as it was recorded during the previous elections (at different levels). The fiscal policy remained the backbone of the overall economic policy on the following two grounds:

- due to a slight economic growth, there was still a need to affect the stimulation of the economic activity through the government fiscal policy;

- in the pre-electoral period, the fiscal policy remained the most important instrument of a possible impact on improving the economic position of the voters - through votes "purchase".

The fiscal trends in Serbia should be viewed in the context of a temporary suspension of cooperation with the IMF (the precautionary impossibility of concluding the second review of the arrangement agreed in September 2011 and worth 1.1 billion euros), which occurred in March 2012, due to the disagreements with the economic policy makers on curbing the budget deficit and the debt issuance. In contrast to the success of the first review in November 2011, which predicted that the budget deficit target in 2012 would be $4.25 \%$ of the GDP, with an expectation that the economic growth in 2012 would be $1.5 \%$, the very unfavourable economic developments indicated that the projected economic growth would not be achieved, and that the deficit would be significantly higher. Therefore, the IMF set the following conditions: a request for the budget revision, a request for the reduction of additional spending and of the debt issuance, the adoption of a medium-term fiscal program and the acceleration of structural reforms. Due to the inability of the economic policy makers to implement significant fiscal tightening measures in the pre-electoral period (the spring of 2012), a temporary suspension of the cooperation with the IMF and the IMF's intention to continue discussions on arrangements with the new government was not surprising.

According to the macroeconomic indicators, the year 2011 was crucial for the negative trends, which later culminated in 2012. A large part of the responsibility for this lies with the economic policy makers. Despite a declarative commitment to a new growth model based on export demand, and thus on significant production and investments into the sectors producing tradable goods, it lacked realization. Instead, during 2011, there was a significant decline in net exports, which partially resulted from the real appreciation of the dinar in 2011 (due to a high influx of foreign capital which, however, was one-off) as well as from the reduced production and export of steel due to the deterioration of the business of U.S. Steel Serbia. In 2011, the current account deficit significantly increased (to $9.2 \%$ of the GDP - primarily due to the reduced inflow of current transfers). In 2012, due to the absence of significant capital inflows from abroad, this trend would continue in a further deficit increase and problems in maintaining the value of the dinar, which would inevitably record depreciation.

However, during the year 2011, favourable trends were recorded in the amount of the foreign direct investment (to recapitalize banks, the investment in retail trade, construction), investments portfolio and other investments. This growth, however, was shortlived and limited, and did not continue in the year 2012. In 2011, the value of the external debt continued to grow in the absolute amount (in millions of euros), while the real appreciation of the dinar decreased the ratio of the debt to the GDP, compared to 2010. The growth of the debt was caused by increased public sector borrowing abroad (with a slight decrease in borrowing by the private sector).

During 2011, inflation was brought under control (the realized inflation at the level of $7 \%$ ), although the growth trend from the previous 2010 continued until May (year-on-year inflation in May was as high as $17.9 \%)$, after which point it stagnated and then declined. In terms of the exchange rate, the appreciation in the first half of the year was followed by its nominal depreciation, which continued into 2012, only curbed in the last quarter of 2012, and the average exchange rate restored the level from the second quarter of 2012.

The economic policy of the pre-electoral period, i.e. in the final months of the previous government, can be said to have been unsystematic and determined by short-term goals. Yet again, the policymakers repeated a significant fiscal expansion that had existed in all the previous pre-electoral periods (in the first half 
of the year 2012, the deficit was as high as 7\% of the GDP). Regardless of such an expansion, the short-term effects on the growth of the economic activity did not materialize. On the contrary, the economic activity declined, a real year-on-year decline in the GDP in Q2 of 2012 was about $0.6 \%$, only to increase in Q3 as a consequence of adverse weather conditions (drought) to $2.2 \%$ of the GDP (year-on-year).

The positive effects on the economic growth did not occur, neither in the short term, but the effects of the wrong dynamics in aggregate demand in terms of the increased inflation and the weakened local currency - namely the dinar did. These effects are recognized in the political macroeconomics models (within the opportunistic political cycle models), but the exploitation of the increased government spending is based on the right "timing", which did not occur in this case. Namely, the Serbian economy was already in recession and the election had to be called and they were scheduled within the final due date (in accordance with the Law), which means that the government did not have much choice with respect to "timing." In the meantime, some unforeseen circumstances occurred, which could not have been affected, or not fast enough.

The positive effects on the economic growth did not materialize, even in the short term, but the effects of a more dynamic aggregate demand on the inflation and the weakened local currency did. These effects are well-known in the political macroeconomics models (within the opportunistic political cycle models), but the success of the increased government spending is based on the right "timing", which did not occur in this case. Namely, the Serbian economy was already in recession and the elections had to be called (their latest due date was scheduled in accordance with the Law), which means that the economic policy makers did not have much choice with respect to "timing." In the meantime, some unforeseen circumstances occurred, which could not have been affected (the bad meteorological conditions in February 2012, which reduced the economic activity, the negative economic trends in the euro area and the growing complexity of the steel plant U.S. Steel Serbia case. Already in December 2011, it was speculated that it would be closed. Instead, the state "bought" the steel plant for a symbolic price of USD1, with a blurred vision of the future, but in order to avoid having about 4,500 workers out of work in the pre-electoral period).

The economic developments in Serbia were bad to the extent that no substantial public spending could reverse them (though in April and part of May, there was an upsurge in industrial production), because there was no increase in net exports and investments. This indicates that the current wrong model of growth and recovery in Serbia suffered a complete collapse, which means that the new economic policy makers will possibly abandon it.

The fact that the economic policy for overcoming the impact of the global economic crisis (2008-2009) was in fact wrong is reflected in the information that the economic activity has not yet reached the level it was at in the spring of 2008 (prior to the effects of the global crisis), but was lower by $3 \%$ in the second quarter of 2012, compared to the same period in 2008. The structure of the GDP use in electoral period completely corresponds to the populist and politically motivated economic policy:

- a significant increase in the government spending (on goods and services, increasing wages) contributed to the year-on-year GDP growth by $2 \%$;

- a growth in private consumption - came from the real growth of the average wage and the real growth of the total spending on pensions - contributed to the GDP growth;

- a decline in investments - contributed to a fall in the GDP;

- a decline in net exports - contributed to a fall in the GDP.

The uncontrolled growth of the government spending in 2012 resulted in the problems of Serbia's public and external debt. The total public debt at the end of the second quarter was $56 \%$ of the GDP, only to rise to as much as $59 \%$ of the GDP at the end of the year (the government borrowings by issuing euro-bonds), which significantly exceeded the required $45 \%$ of the GDP. In addition to borrowing abroad, the government also borrowed in the country (by issuing Treasury bills). However, the amount of external debt indicates that, at the end of 2012, it will exceed $80 \%$ of the GDP, with a high cost of its repayment in the future. In order 
to eliminate a threat of the foreign insolvency of the country and given that in 2012, there was a decline in the foreign currency reserves, it is necessary to have those economic policy measures which would reduce the current account deficit, i.e. increase exports, limit domestic demand and lead to the acceptance of the exchange rate policy based on the sustainable exchange rate (abandoning the overvalued dinar and the maintenance of an artificial exchange rate at the expense of spending the foreign exchange reserves).

The economic policy of the new government is facing significant limitations - dynamising domestic demand has peaked and no longer can it be counted on, the stimulating of the economic activity by means of the economic policy measures is very limited and can be related to a possible use of the exchange rate policy, primarily through its depreciation with the aim of improving Serbia's price competitiveness and exports. This leads to the conclusion that it is necessary that the system of economy and business operations in Serbia should be reformed. In this context, some measures to facilitate business procedures, various permits (including construction permits) obtaining procedures, tax procedures and most importantly - the elimination of all forms of corrupt behavior in business operations - have been announced.

The first task for the new government was to consolidate public finance, which is not uncommon either in terms of the past experience regarding the pre-electoral fiscal developments in Serbia or in terms of what models of political budget cycles we are taught. Such a high deficit and the debt increase are fully compliant with the assumption that in a situation where policy makers face a prospect of losing power, they opt for an extremely expansionary economic policy. In addition to the budget deficit, as a pressing issue, there was also the high inflation, and the depreciation of the dinar. This third problem - the decreased value of the dinar (nominal and real), was the first to initially be eliminated by nominal and then substantial real appreciation of the exchange rate (due to a high inflation rate, and a relatively stable nominal exchange rate). To solve the problem of inflation and depreciation, in addition to fiscal restrictions, it was also necessary to have a restrictive monetary policy, which the National Bank of Serbia's new governor continued as well. Amongst these measures, there certainly was a further increase in the reference interest rate, an increase in the dinar share in the foreign exchange reserve requirement, and the transition to standard repo operations.

In the future period, the fiscal policy will be the backbone of the economic policy, much as it was the case with the previous government. In the public finance domain, the new government has taken steps in limiting the government spending. At least officially, new economic policy makers consider that a future economic recovery and economic growth will not be based on an unrealistic growth in domestic demand, primarily in the government spending. One must not forget, however, that the previous government also adopted the "new growth model" in 2011, which was thought to have brought an end to the practice of growth based on domestic demand. Although officially adopted, this model has not taken root in practice, nor has it been supported by relevant economic policy measures.

\section{CONCLUSION}

The paper demonstrates that the economic policies to overcome the effects of the global economic crisis in Serbia have had mixed effects. The short-term, positive effects in the form of a slight recovery since 2010 have materialised, but in the medium term, the economic policy has failed. This has largely been so due to the significant restrictions that already existed in the period before the onset of the global economic crisis, such restrictions being the legacy of a high budget deficit and the poor state of public finances as well as a wrong model of growth based on the growth of domestic demand. These problems have deepened due to the necessity of the significant state intervention in the economy and a fiscal expansion. As a necessary way to stimulate the economic activity in the period of the economic crisis, the fiscal stimulus in Serbia has been related to the continuation of the opportunistic and partisan-motivated abuses of the economic policy. This paper demonstrates that throughout the period before, during and after the effect of the global economic crisis, the fiscal policy in Serbia has significantly been influenced by the political factors 
that caused its abuse in ways known in the literature of political macroeconomics. At the same time, the monetary policy has primarily served the purpose of maintaining price stability, often trying to limit the negative effects of the fiscal measures. Therefore, no coordination can be said to have been existing between the monetary and fiscal policies. The worsening economic trend was particularly evident in the last months of the previous government, right before and especially after the elections.

The political manipulation of the economic policy present in the earlier years has left a bad legacy to new monetary policy makers, conditioning some of their first moves. Thus, they have been imposed the necessity of fiscal consolidation, as stated in the models of the political budget cycles. Taking into account all the limitations of the growth model used until recently - the one based on domestic demand - monetary policy makers are left with no possibility of using it any longer. They rather need to focus on finding new sources of growth - especially exports, for which it is necessary to have production started, but structural reforms and the ever-so-delayed reform of the public sector are of equal importance as well. This provides a certain dose of optimism that the future will not repeat the mistakes - the intentional use of the economic policy instruments for political purposes, because the possibilities for this have almost completely been exhausted (extremely high fiscal deficits, a high public debt, the problem of curbing inflation).

\section{ACKNOWLEDGMENTS}

This paper is a part of the interdisciplinary research Project (No. 179065), which is funded by the Ministry of Sciences of the Republic of Serbia.

\section{REFERENCES}

Alesina, A. (1987). Macroeconomic Policy in a Two-Party System as a Repeated Game. Quarterly Journal of Economics, 102(3), 651-678.

Alesina, A., \& Tabellini, G. (1990). A Positive Deficits of Fiscal Deficits and Government Debt. Review of Economic Studies, $57,403-414$.
Alesina, A., \& Drazen, A. (1991). Why Are Stabilizations Delayed? American Economic Review, 81(5), 1170-1188.

Cukierman, A., \& Meltzer, A. (1986). A Positive Theory of Discretionary Policy, the Cost of Democratic Government, and the Benefits of a Constitution. Economic Inquiry, 24, 367388 .

Drazen, A. (2000). The Political Cycles After 25 Years. NBER Macroeconomic Annual, Cambridge. Mass: MIT Press.

Hibbs, D. (1977). Political Parties and Macroeconomic Policy. American Political Science Review, 71 (4), 1467-1487.

Jakšić, M., i Praščević, A. (2010). Politička makroekonomija. Beograd: Ekonomski fakultet Univerziteta u Beogradu.

Nordhaus, W. (1975). The Political Business Cycle. Review of Economic Studies, 42(2), 169-190.

Persson, T., \& Svensson, L. (1989). Why a Stubborn Conservative Would Run a Deficit: Policy With Time-Inconsistent Preferences. Quarterly Journal of Economics, 104, 325 - 345.

Persson, T., \& Tabellini, G. (1990). Macroeconomic Policy, Credibility, and Politics. Chur, Switzerland: Harwood Academic Publishers.

Praščević, A. (2008a). Poslovni ciklusi u makroekonomskoj teroiji $i$ politici, Beograd: Ekonomski fakultet Univerziteta $\mathrm{u}$ Beogradu.

Praščević, A. (2008b). Politički faktori makroekonomske nestabilnosti u Srbiji. U M. Zec, i B. Cerović (Urednici), Kuda ide Srbija? - Ostvarenja i dometi reformi (str. 43-69). Beograd: Naučno društvo ekonomista i Ekonomski fakultet Univerziteta $u$ Beogradu.

Praščević, A. (2010). Odnos javnost - elita i brzina reformskih procesa u Srbiji: Zašto su reforme u Srbiji usporene? U M. Arandarenko, A. Praščević, i S. Cvejić (Urednici), Ekonomsko - socijalna struktura Srbije: Učinak proe decenije tranzicije (str. 87-105). Beograd: Naučno društvo ekonomista i Ekonomski fakultet Univerziteta u Beogradu.

Praščević, A. (2012a). Development of Modern Macroeconomics in the Context of Global Economic Crisis. In B. Cerović, M. Jakšić, Z. Mladenović, \& A. Praščević (Eds.), From Global Crisis to Economic Growth. Which Way to Take?, (pp. 603-629). Belgrade: Faculty of Economics of the University of Belgrade.

Praščević, A. (2012b). The Role of Government in Overcoming the Effects of Global Economic Crisis in Serbia - Obstacles from the Past. Montenegrin Journal of Economics, 8(1), 137-155.

Radisavljević, G. (2010), Lična potrošnja u Republici Srbiji, 20002009, Studije i analize. Beograd, Republika Srbija: Republički zavod za statistiku.

Rogoff, K., \& Sibert, A. (1988). Elections and Macroeconomic Policy Cycles. Review of Economic Studies, 55, 1-16. 
Rogoff, K. (1990). Equilibrium political budget cycles. American Economic Review, 80, 21-36.

Spilimbergo, A., Symansky, S., Blancard, O., \& Cottarelli, C. (2008). Fiscal Policy for the Crisis. IMF Staff Position Note. Retrived July 7, 2010, from http://www.imf.org/external/ pubs/ft/spn/2008/spn0801.pdf

Stamenković, S., Kovačević, M., Vučković, V., Nikolić, I. i Bušatlija, M. (2009). Ekonomska politika u 2010. godini: ka novom modelu ravnoteže. U B. Zivković, i S. Stamenković (Urednici), Ekonomska politika Srbije u 2010. g. - Ka novom modelu makroekonomske stabilnosti (str. 15-69). Beograd: Naučno društvo ekonomista i Ekonomski fakultet Univerziteta u Beogradu.

Narodna banka Srbije. Statistika - Osnovni makroekonomski indikatori. Retrived March 1, 2013, from http://www.nbs.rs.

Narodna banka Srbije. Statistika - Platni bilans RS. Retrived March 1, 2013, from http://www.nbs.rs.

Republički zavod za statistiku. Anketa o radnoj snazi. Retrived Febuary 7, 2013, from http://webrzs.stat.gov.rs.

Received on $11^{\text {th }}$ March 2013, after revision, accepted for publication on $19^{\text {th }}$ April 2013

Aleksandra Prascevic is an Associate Professor at the Faculty of Economics, University of Belgrade, teaching the courses of Basics of Macroeconomics, Macroeconomic Analysis, and History of Economics. A particularly important part of the scientific work of Aleksandra Prascevic PhD is political macroeconomics, especially its segment related to the politically generated cyclical macroeconomic fluctuations. 


\title{
DOMETI EKONOMSKE POLITIKE U PREVAZILAŽENJU EFEKATA GLOBALNE EKONOMSKE KRIZE NA EKONOMIJU SRBIJE
}

\author{
Aleksandra Praščević* \\ Ekonomski fakultet Univerziteta u Beogradu
}

Rad je posvećen temi u kojoj je meri ekonomska politika u Srbiji uspela da odgovori na ekonomske probleme nametnute uticajem globalne ekonomske krize i koliko su ograničenja u vidu političke nestabilnosti i političkog uticaja, inače prisutni i pre krize, uticali i na ekonomsku politiku formulisanu u cilju borbe protiv krize. Ekonomska kriza je na globalnom nivou uticala da se, umesto pravila u vođenju ekonomske politike sa ključnim ciljem održanja cenovne stabilnosti, promoviše diskrecija i fiskalna politika, sa ciljem prevazilaženja problema nezaposlenosti. Značajnija primena diskrecije u ekonomskoj politici i inače nameće problem kompetentnosti i eventualnih političkih motiva kreatora ekonomske politike. Upravo su ograničenja nedovoljno razvijenih institucija i pogrešnog modela rasta doprinela da rezultati ekonomske politike u Srbiji ne budu značajni. Srbija se suočava sa negativnim posledicama primenjenih mera u vidu visokog budžetskog deficita, javnog duga i inflacije, dok su efekti na privrednu aktivnost i zaposlenost izostali, zbog čega je aktuelan izbor između pravila i diskrecije.

Ključne reči: globalna ekonomska kriza, ekonomska politika, politička makroekonomija

\section{UVOD}

Globalna ekonomska kriza (2007-2009), koju je otpočela finansijska kriza i ekonomska recesija u SAD-u, oficijelno u decembru 2007. godine, kao jedinstveni ekonomski događaj koji se ne može podvesti pod standardni ciklični pad ekonomske aktivnosti, dovela je do značajnih promena u ciljevima i instrumentima ekonomske politike (Praščević, 2012a, 626). Nakon

\footnotetext{
* Korespondencija: A. Praščević, Ekonomski fakultet Univerziteta u Beogradu, Kamenička 6, 11000 Beograd, Srbija; e-mail:alja@ekof.bg.ac.rs
}

decenijske dominacije pravila $\mathrm{u}$ vođenju ekonomske politike i primarnog cilja cenovne stabilnosti oslanjanjem na monetranu politiku, potrebe za ublažavanjem i što bržim prevazilaženjem ekonomske krize nametnule su diskreciju u vođenju ekonomske politike, a naročito fiskalne politike (Spilimbergo, et al, 2008). Takođe, kao ključni ekonomski problem izdvojila se nezaposlenost, zbog čega se ekonomska politika, a opet najviše fiskalna politika, okrenula prevazilaženju ovog problema.

Navedene promene $u$ ciljevima $i$ korišćenim instrumentima ekonomske politike, nametnule su 
pitanje da li je reč o definitivnoj promeni $\mathrm{u}$ domenu makroekonomske teorije (napuštanje neoliberalne paradigme), odnosno, da li je reč o suštinskoj promeni ekonomske politike (napuštanje pravila i povratak diskrecije), ili je reč o kratkoročnom povratku kejnzijanizma. U godinama nakon globalne ekonomske krize, koje su obeležene sporim oporavkom i problemima javnih finansija, gotovo u svim zemljama koje je kriza pogodila, razmatraju se efekti preduzetih mera za prevazilaženje krize.

Cilj ovog rada je utvrđivanje efekata preduzetih mera ekonomske politike radi prevazilaženja negativnih uticaja globalne ekonomske krize (2007-2009) u Srbiji. $\mathrm{U}$ radu se razmatraju ključni elementi preduzete, prvenstveno, fiskalne stimulacije, ali i uticaj monetarne politike. Efekti preduzetih mera ekonomske politike, u radu se razmatraju i u kontekstu činjenice da im je prethodio period izuzetne fiskalne ekspanzije koji je bio primarno politički motivisan - političkom nastabilnošću i modelom rasta baziranom na domaćoj tražnji.

U radu se razmatra hipoteza da je primenjena ekonomska politika radi prevazilaženja ekonomske krize bila delimično motivisana stvarnom potrebom da se podstakne privredna aktivnost, ali i da je delimično nastavljeno sa ranije politički generisanim stimulisanjem, u čijoj je osnovi bila kombinacija oportunističkih i stranačkih motiva. Ranije zloupotrebe ekonomske politike u Srbiji su pri tome značajno ograničile mogućnosti korišćenja ekonomske politike u svrhe prevazilaženja ekonomske krize.

U radu se koriste relevantni podaci - makroekonomski pokazatelji u Srbiji za period koji se analizira, a primenjuju se ključne postavke razvijenih modela političkih ciklusa - oportunističkih i stranačkih (Nordhaus, 1975; Hibs, 1977; Rogof, 1990; Rogoff \& Sibert, 1988; Alesina, 1987).

Rad se nakon uvoda, sastoji iz sledećih delova: Efekti globalne ekonomske krize na privredu Srbije, Fiskalna politika - način za prevazilaženje recesionih pritisaka ili izvor političkih manipulacija, Ekonomska politika u predizbornom periodu i nova ekonomska politika, Zaključak.

\section{EFEKTI GLOBALNE EKONOMSKE KRIZE NA PRIVREDU SRBIJE}

Globalna ekonomska kriza značajno je uticala i na ekonomiju Srbije. Usporavanje svetske privrede, problemi finansijskog sektora i funkcionisanja finansijskog sistema, koji su značajno otežali globalno kreditiranje i smanjili likvidnost, imali su negativne posledice i na ekonomije sa nastajućim tržištima i ekonomije u tranziciji, među kojima je i ekonomija Srbije. Ove posledice su se odnosile kako na problem smanjenja globalne agregatne tražnje, koja je za rezultat imala usporavanje privredne aktivnosti i smanjenje izvoza, tako i na smanjenje priliva kapitala $\mathrm{u}$ vidu investicija i na rast cena zaduživanja zbog smanjene globalne likvidnosti.

Početak prelivanja krize u Srbiju desio se u poslednjem kvartalu 2008. godine i najpre je bio obeležen strahom od značajnijeg udara na bankarski sektor, usled učestalih bankrotstava finansijskih institucija u svetu. Međutim, pored kratkoročnog efekta na povlačenje devizne štednje iz banaka u Srbiji (tokom oktobra 2008. godine povučeno je oko 1 mlrd evra), značajniji efekti su sprečeni i bankarski sektor je ostao stabilan, a mere kojima je država garantovala za depozite, dovele su do stabilizacije i povratka štednje $u$ banke.

Najjači udar krize na privredu Srbije zabeležen je 2009. godine u kojoj je po prvi put od političkih promena 2000. godine zabeležen pad BDP-a (Tabela 1). Značajno usporavanje privredne aktivnosti beleži se već $u$ drugoj polovini 2008. godine, kao posledica smanjenja agregatne tražnje i to obe komponente - domaće i izvozne tražnje. Značajniji efekat imao je pad domaće tražnje, iako je on bio manji od smanjenja izvozne tražnje, ali je zbog značajnijeg učešća u ukupnoj tražnji njeno smanjivanje značajnije uticalo na usporavanje privredne aktivnosti. (Praščević, 2012b, 144)

Sve makroekonomske veličine tokom 2009. godine ukazuju na nepovoljna ekonomska kretanja. Iako je, svakako, efekat globalne ekonomske krize bio odlučujući za njih, ipak je važno uočiti da su greške $\mathrm{u}$ vođenju ekonomske politike $\mathrm{u}$ periodu pre 2008. godine, takođe, imale svoj udeo u ovako lošim pokazateljima (Stamenković i ostali, 2009, 24). Prvenstveno se to odnosi na dva unutrašnja faktora: 
Tabela 1 Ključni makroekonomski indikatori u Srbiji (2002-2012)

\begin{tabular}{|c|c|c|c|c|c|c|c|c|c|c|c|c|c|c|}
\hline & 2002 & 2003 & 2004 & 2005 & 2006 & 2007 & 2008 & 2009 & 2010 & 2011 & $\begin{array}{c}\text { Q1 } \\
2012\end{array}$ & $\begin{array}{c}\text { Q2 } \\
2012\end{array}$ & $\begin{array}{c}\text { Q3 } \\
2012\end{array}$ & $\begin{array}{c}\text { Q4 } \\
2012\end{array}$ \\
\hline $\begin{array}{l}\text { Realni rast BDP-a } \\
(\mathrm{u} \%)\end{array}$ & 4.3 & 2.5 & 9.3 & 5.4 & 3.6 & 5.4 & 3.8 & -3.5 & 1.0 & 1.6 & -2.3 & -0.6 & -2.5 & -1.5 \\
\hline $\begin{array}{l}\text { Potrošačke cene } \\
\text { (u \%, relativno u } \\
\text { odnosu na isti } \\
\text { mesec prethodne } \\
\text { godine) }\end{array}$ & 14.8 & 7.8 & 13.7 & 17.7 & 6.6 & 11.0 & 8.6 & 6.6 & 10.3 & 7.0 & 3.2 & 5.5 & 10.3 & 12.2 \\
\hline $\begin{array}{l}\text { NBS devizne } \\
\text { rezerve foreign (u } \\
\text { EUR mil.) }\end{array}$ & 2,186 & 2,836 & 3,104 & 4,921 & 9,020 & 9,634 & 8,162 & 10,602 & 10,002 & 12,058 & 11,073 & 10,161 & 9,833 & 10,914 \\
\hline Izvoz (u EUR mil.) & 3,125 & 3,847 & 4,475 & 5,330 & 6,949 & 8,686 & 10,157 & 8,478 & 10,070 & 11,486 & 2,519 & 3,031 & 3,083 & $3.293,6$ \\
\hline $\begin{array}{l}\text { - stopa rasta u \% } \\
\text { u odnosu na pre- } \\
\text { thodnu godinu }\end{array}$ & 16.0 & 23.1 & 16.3 & 19.1 & 30.4 & 25.0 & 16.9 & -16.5 & 18.8 & 14.1 & -2.6 & 5.2 & 3.2 & 8,7 \\
\hline Uvoz (u EUR mil.) & $-6,387$ & $-7,206$ & $-9,543$ & $-9,613$ & $-11,971$ & $-16,016$ & $-18,843$ & $-13,404$ & $-14,643$ & $-16,627$ & $-4,042$ & $-4,323$ & $-4,235$ & $-4.620,7$ \\
\hline $\begin{array}{l}\text { - stopa rasta u \% } \\
\text { u odnosu na pre- } \\
\text { thodnu godinu }\end{array}$ & 27.2 & 12.8 & 32.4 & 0.7 & 24.5 & 33.8 & 17.7 & -28.9 & 9.2 & 13.6 & 5.5 & 6.3 & 1.3 & 1,6 \\
\hline $\begin{array}{l}\text { Bilans tekućeg } \\
\text { računa: }\end{array}$ & & & & & & & & & & & & & & \\
\hline u EUR mil. & -671 & $-1,347$ & $-2,620$ & $-1,778$ & $-2,356$ & $-5,053$ & $-7,054$ & $-1,910$ & $-1,887$ & $-2,856$ & $-1,177$ & -738 & -546 & $-685,8$ \\
\hline kao \% BDP-a & -4.2 & -7.8 & -13.8 & -8.8 & -10.1 & -17.7 & -21.6 & -6.6 & -6.7 & -9.2 & -16.9 & -10.2 & -7.3 & $-8,3$ \\
\hline $\begin{array}{l}\text { Nezaposlenost } \\
\text { prema Anketi } \\
\text { (u\%) }\end{array}$ & 13.3 & 14.6 & 18.5 & 20.8 & 20.9 & 18.1 & 13.6 & 16.1 & 19.2 & 23.0 & 1 & 25.5 & 1 & 22.4 \\
\hline $\begin{array}{l}\text { Plate (prosečna za } \\
\text { period, u EUR) }\end{array}$ & 152.1 & 176.9 & 194.6 & 210.4 & 259.5 & 347.6 & 402.42 & 337.9 & 330.1 & 372.5 & 357.6 & 363.2 & 351.8 & 385.3 \\
\hline $\begin{array}{l}\text { RS budžetski } \\
\text { deficit/suficit } \\
\text { (\% BDP-a) }\end{array}$ & -4.3 & -2.6 & -0.3 & 0.3 & -1.9 & -1.7 & -1.7 & -3.4 & -3.7 & -4.2 & -7.0 & -7.1 & -3.9 & -5.0 \\
\hline $\begin{array}{l}\text { Konsolidovani } \\
\text { fiskalni rezultat } \\
\text { (\% BDP-a) }\end{array}$ & -1.8 & -2.4 & 0.8 & 0.9 & -1.9 & -2.0 & -2.6 & -4.5 & -4.7 & -5.0 & -7.3 & -6.9 & -4.1 & -7.3 \\
\hline $\begin{array}{l}\text { RS javni dug, } \\
\text { (spoljni + } \\
\text { unutrašnji, \% } \\
\text { BDP-a) }\end{array}$ & 72.9 & 66.9 & 55.3 & 52.2 & 37.7 & 31.5 & 29.2 & 34.7 & 44.5 & 48.7 & 52.0 & 56.0 & 55.1 & 59.2 \\
\hline $\begin{array}{l}\text { RSD/EUR devizni } \\
\text { kurs (prosek za } \\
\text { period) }\end{array}$ & 60.66 & 65.13 & 72.70 & 83.00 & 84.10 & 79.96 & 81.44 & 93.95 & 103.04 & 101.95 & 108.11 & 113.73 & 116.95 & 113.45 \\
\hline $\begin{array}{l}\text { RSD/EUR devizni } \\
\text { kurs (kraj perioda) }\end{array}$ & 61.52 & 68.31 & 78.89 & 85.50 & 79.00 & 79.24 & 88.60 & 95.89 & 105.50 & 104.64 & 111.36 & 115.82 & 115.03 & 113.72 \\
\hline
\end{tabular}

Izvor: Narodna banka Srbije. Statistika - Osnovni makroekonomski indikatori. 
- izbor modela privrednog rasta baziranog na agregatnoj tražnji, i to domaćoj tražnji; i

- politička nastabilnost i vođenje ekonomske politike u uslovima koalicionih vlada.

Ovi faktori su međusobno povezani i uslovljeni. Najpre je izbor modela rasta, koji je generisao nedovoljno dinamičan razvoj i unutrašnje i spoljne neravnoteže, imao svoje uporište $u$ političkim faktorima koji su dominirali u periodu nakon 2000. godine, a koji se najjednostavnije mogu definisati kao politička nestabilnost. Iako se ona u literaturi definiše na različite načine i uključuje različite elemente (Praščević, 2008a, 259-261), u Srbiji se u periodu 20002008, politička nestabilnost može poistovetiti sa čestim izborima na različitim nivoima (Praščević, 2008b, 50) i značajnim političkim razlikama između političkih partija, a naročito između koalicionih partnera u samoj vladi. Zbog toga su, pored čestih izbora, bile prisutne i veoma jake tenzije $u$ okviru vlada koje su se često ticale političkih pitanja (brzine političkih reformi koje su zahtevane radi priključenja EU), ali i ekonomskih pitanja. Među najvažnijim su bile: nesuglasice $u$ okviru vlade (2003-2007) koje su se dešavale od maja 2006. godine, a u vezi sa zamrzavanjem pregovora o Stabilizaciji i asocijaciji sa EU iz političkih razloga, što je okončano raspisivanjem redovnih izbora u novembru 2006. godine za januar 2007. godine (predizborna kampanja je trajala još od maja 2006. godine, a što je upravo period $\mathrm{u}$ kome je došlo do promena $\mathrm{u}$ vidu izrazite ekspanzivnosti fiskalne politike), nesuglasice u kolacionoj vladi (2007-2008) do kojih je došlo već krajem 2007. godine, a koje su okončane prevremenim izborima 2008. godine (čitava 2007. godina je obeležena značajnom fiskalnom ekspanzijom), nesuglasice u okviru koalicione vlade (2008-2012) koje su se prvenstveno odnosile na ekonomska pitanja $u$ februaru 2011. godine, a zbog kojih nije došlo do pada, ali jeste do rekonstrukcije vlade, kao i dugoročnih posledica na međusobno udaljavanje dotadašnjih važnih koalicionih partnera.

Za ključne epizode ekonomske politike vođene $\mathrm{u}$ Srbiji, postavke političke makroekonomije o mogućoj zloupotrebi ekonomske politike od strane njenih kreatora, dolazile su do izražaja u obe svoje forme oportunističkih i stranačkih motiva (Jakšić i Praščević, 2010, 17-18). Za realizaciju svojih oportunističkih ciljeva, srpska politička elita dobijala je podršku srpske ekonomske elite, makar jednog njenog dela, što je uslovilo kako izbor modela rasta, tako i preduzimanje konkretnih mera ekonomske politike, ali i najpogubnije - izbor gotovo u potpunosti disfunkcionalnih institucija. Ovakav izbor imao je dugoročne negativne posledice po ekonomska kretanja.

Česti izbori bili su jedan od ključnih razloga za usporavanje reformi, s obzirom da se iz izbora $\mathrm{u}$ izbore smanjivala podrška za brze i radikalne reforme. Politička elita (proreformska i proevropska) se opredeljivala za značajniju "kupovinu" glasača, upravo $\mathrm{u}$ formi povećanja kupovne moći i standarda stanovništva, iznad mogućnosti koje je diktirao privredni rast (Praščević, 2010, 94.). Rast domaće tražnje bio je primarno finansiran prilivom kapitala iz inostranstva i to po osnovu privatizacije, što je značilo jednokratni priliv sredstava. Ovakav rast je doživeo svoj krah sa otpočinjanjem globalne ekonomske krize kada su greške ekonomske politike počele da izlaze na svetlost dana, pogoršavajuči i onako loše ekonomsko stanje.

Pokazatelji kretanja stvarne lične potrošnje u Srbiji ukazuju na njeno izrazito učešće u BDP-u (čak iznad $90 \%$ ), što je više od svih ostalih zemalja, a značajno iznad proseka za EU27 zemlje (Radisavljević, 2010, 28). Ovakav nivo stvarne lične potrošnje predstavlja značajno ograničenje ekonomskom rastu. Međutim, kada se u obzir uzme visina realne stvarne lične potrošnje per capita i ona uporedi sa ostalim zemljama EU i Zapadnog Balkana, uočava se da je ona u periodu 2005-2009 dostizala od 38 do 45\% proseka za EU27, dok je $\mathrm{u}$ istom periodu indeks za BDP iznosio 32 do 37\% proseka ostvarenog u EU27 (Radisavljević, 2010, 32). Dakle, rast stvarne lične potrošnje bio je brži u odnosu na rast BDP-a, ali se Srbija po visini stvarne lične potrošnje per capita može svrstati i porediti sa zemljama Zapadnog Balkana.

Ekonomija Srbije je i pre globalne krize imala značajan problem sa spolinotrgovinskom neravnotežom, kao i fiskalnim deficitom. Međutim, i tako mali obim izvoza tokom 2009. godine zabeležio je pad od 16,5\%, $\mathrm{u}$ odnosu na prethodnu godinu. Istovremeno je, zbog pada domaće tražnje, ali i proizvodnje došlo do još značajnijeg pada uvoza za čak $28,9 \%$ u odnosu na 
Tabela 2 Platni bilans Srbije (2007-2011)

\begin{tabular}{|c|c|c|c|c|c|c|}
\hline \multicolumn{2}{|c|}{ STAVKE } & 2007. & 2008. & 2009 & 2010. & 2011. \\
\hline \multicolumn{2}{|c|}{ I. TEKUĆI RAČUN } & $-5,052.5$ & $-7,054.2$ & $-1,910.1$ & $-1,887.2$ & $-2,776.0$ \\
\hline \multicolumn{2}{|r|}{ TEKUĆI RAČUN BEZ ZVANIČNE POMOĆI } & $-5,218.9$ & $-7,216.8$ & $-2,107.6$ & $-2,080.3$ & $-2,976.1$ \\
\hline \multicolumn{2}{|r|}{ 1. Roba (1.1-1.2.) } & $-7,068.7$ & $-8,501.2$ & $-4,946.4$ & $-4,581.0$ & $-5,318.4$ \\
\hline \multicolumn{2}{|r|}{ 1.1. Izvoz robe f.o.b. } & $6,382.5$ & $7,416.0$ & $5,977.8$ & $7,402.5$ & $8,439.7$ \\
\hline \multicolumn{2}{|r|}{ 1.2. Uvoz robe, f.o.b } & $-13,451 \cdot 3$ & $-15,917.2$ & $-10,924 \cdot 2$ & $-11,983.6$ & $-13,758.1$ \\
\hline \multicolumn{2}{|r|}{ 2. Usluge (2.1.-2.2.) } & -261.1 & -184.7 & 20.5 & 7.7 & 163.2 \\
\hline \multicolumn{2}{|r|}{ 2.1. Prihodi } & $2,304.0$ & $2,741.4$ & $2,500.0$ & $2,667.1$ & $3,032.3$ \\
\hline \multicolumn{2}{|r|}{ 2.2. Rashodi } & $-2,565.1$ & $-2,926.1$ & $-2,479.5$ & $-2,659 \cdot 4$ & $-2,869.1$ \\
\hline \multicolumn{2}{|r|}{ 3. Bilans roba i usluga (3.1.-3.2.) } & $-7,329 \cdot 9$ & $-8,685.9$ & $-4,925.8$ & $-4,573.3$ & $-5,155.2$ \\
\hline \multicolumn{2}{|r|}{ 3.1. Izvoz roba i usluga } & $8,686.5$ & $10,157 \cdot 3$ & $8,477.8$ & $10,069.6$ & $11,472.0$ \\
\hline \multicolumn{2}{|r|}{ 3.2. Uvoz roba i usluga } & $-16,016.4$ & $-18,843.2$ & $-13,403.6$ & $-14,642.9$ & $-16,627.2$ \\
\hline \multicolumn{2}{|r|}{ 4. Dohodak } & -598.7 & -921.8 & -502.5 & -669.9 & -757.9 \\
\hline \multicolumn{2}{|r|}{ 4.1. Prihodi } & 516.9 & 558.1 & 499.7 & 437.7 & 428.2 \\
\hline \multicolumn{2}{|r|}{ 4.2. Rashodi } & $-1,115.6$ & $-1,479 \cdot 9$ & $-1,002.1$ & $-1,107 \cdot 5$ & $-1,186.2$ \\
\hline \multicolumn{2}{|r|}{ 5. Tekući transferi } & $2,876.1$ & $2,553.6$ & $3,518.2$ & $3,356.0$ & $3,137.1$ \\
\hline \multicolumn{2}{|r|}{ 5.1. Prihodi } & $3,104 \cdot 7$ & $2,828.3$ & $3,762.0$ & $3,624.0$ & $3,488.2$ \\
\hline \multicolumn{2}{|r|}{ 5.2. Rashodi } & -228.6 & -274.7 & -243.8 & -268.0 & -351.0 \\
\hline \multicolumn{2}{|c|}{ II. KAPITALNI RAČUN } & -313.9 & 13.2 & 1.6 & 0.9 & -2.5 \\
\hline \multicolumn{2}{|c|}{ III. FINANSIJSKI RAČUN } & $5,175.6$ & $7,133 \cdot 3$ & $2,032.6$ & $1,818.5$ & $2,609.2$ \\
\hline \multicolumn{2}{|r|}{ 1. Direktne investicije - neto } & $1,820.8$ & $1,824 \cdot 4$ & $1,372.5$ & 860.1 & $1,826.9$ \\
\hline \multicolumn{2}{|r|}{ 2. Portfolio investicije - neto } & 678.2 & -90.9 & -51.0 & 38.8 & $1,619.1$ \\
\hline \multicolumn{2}{|r|}{ 3. Ostale investicije } & $3,418.7$ & $3,713.2$ & $3,074.6$ & -9.1 & 964.6 \\
\hline & 3.1. Aktiva (potraživanja) & $-1,618.3$ & $-1,451.1$ & 75.3 & -791.9 & 455.4 \\
\hline & 3.1.1. Trgovinski krediti & -860.0 & -601.5 & -394.7 & -368.9 & -300.2 \\
\hline & 3.1.2. Finansijski krediti & 1.1 & -30.5 & 24.8 & -34.0 & -18.4 \\
\hline & 3.1.3. Gotov novac i depoziti & -710.3 & -787.9 & 445.2 & -389.0 & 774.0 \\
\hline & 3.1.4. Ostala aktiva & -49.1 & -31.2 & & & \\
\hline & 3.2. Pasiva (obaveze) & $5,037.0$ & $5,164 \cdot 3$ & $2,999.2$ & 782.8 & 509.2 \\
\hline & 3.2.1. Trgovinski krediti & $1,619.2$ & $1,558.6$ & 873.9 & 284.6 & 808.3 \\
\hline & 3.2.2. Finansijski krediti & $3,402.1$ & $3,529.2$ & $1,388.7$ & 863.5 & -394.6 \\
\hline & 3.2.2.1. NBS & -91.5 & 0.0 & $1,114 \cdot 4$ & 341.0 & 44.8 \\
\hline & 3.2.2.2. Vlada & 121.1 & 98.4 & 258.2 & 735.3 & 687.5 \\
\hline & 3.2.2.2.1. Dugoročni & 121.1 & 116.3 & 256.7 & 736.8 & 687.5 \\
\hline & 3.2.2.2.2. Kratkoročni & & -17.9 & 1.5 & -1.5 & \\
\hline & 3.2.2.3. Banke & 166.6 & 155.4 & 869.1 & 659.7 & -710.8 \\
\hline & 3.2.2.3.1. Dugoročni & -126.3 & -260.2 & 474.2 & 651.9 & 437.8 \\
\hline & 3.2.2.3.2. Kratkoročni & 292.9 & 415.6 & 394.9 & 7.8 & $-1,148.5$ \\
\hline & 3.2.2.4. Ostali sektori & $3,205.9$ & $3,275 \cdot 3$ & -853.0 & -872.4 & -416.1 \\
\hline & 3.2.3. Gotov novac i depoziti & 68.8 & 75.3 & 314.5 & -365.3 & 95.6 \\
\hline & 3.2.4. Ostala pasiva & -53.1 & 1.2 & & & \\
\hline & 3.2.5. Alokacija SPV & & & 422.2 & & \\
\hline & Sredstva rezervi & -742.1 & $1,686.6$ & $-2,363.5$ & 928.7 & $-1,801.5$ \\
\hline IV & SREŠKE I PROPUSTI-neto & 190.8 & -92.3 & -124.1 & 67.8 & $169 \cdot 3$ \\
\hline & JKUPNI BILANS & 742.1 & $-1,686.6$ & $2,363.5$ & -928.7 & $1,801.5$ \\
\hline
\end{tabular}

Izvor: Narodna banka Srbije. Statistika - Platni bilans RS. 
prethodnu godinu. To je uslovilo poboljšanje deficita tekućeg računa koji je iznosio 6,6\% BDP-a, u odnosu na 21,6\% BDP-a iz 2008. godine (Tabela 1), kao posledica smanjivanja ukupne trgovinske razmene Srbije sa inostranstvom. Kako se krajem 2009. godine privredna aktivnost oporavljala tako se ponovila tendencija bržeg rasta uvoza u odnosu na rast izvoza (prosečno $6 \% \mathrm{u}$ odnosu na $4 \%$ ), zbog čega je došlo do rasta deficita tekućeg računa, kao i robnih deficita.

Tokom perioda najjačeg uticaja krize na privredu Srbije u 2009. godini, suficit finansijskog računa je smanjen u odnosu na 2008. godinu. Tome je doprineo pad neto stranih direktnih investicija (sa 1.824 miliona evra na 1.372 miliona evra), deficit portfolio investicija je smanjen sa 91 miliona na 51 milion, a pad su zabeležile i ostale investicije (sa 3.713 na 3.075 miliona evra). U okviru ove stavke bili su značajni finansijski krediti i to oni uzeti od strane bankarskog sektora (kratkoročni krediti), kao i tranša kredita MMF-a državi (iz stendbaj aranžmana 1.114 miliona evra i 422 miliona evra kroz specijalna prava vučenja), ali i priliv gotovog novca i depozita (Tabela 2). Istovremeno je, tokom 2009. godine, došlo do rasta deviznih rezervi od 2.363,5 miliona evra (doprinela sredstva dobijena od MMF-a od 1,54 mlrd. evra i 400 miliona evra od prodaje NIS-a), za razliku od pada ovih rezervi u 2008. godini za 1.686,6 miliona evra.

Tokom recesione 2009. godine, stopa inflacije je opadala (ukupna godišnja 6,6\%, u odnosu na 2008. godinu kada je bila $8,6 \%$ ), što odgovara teorijskim objašnjenjima, odnosno, što se moglo smatrati posledicom smanjenja domaće tražnje (usled zamrzavanja plata $\mathrm{u}$ javnom sektoru i rasta nezaposlenosti - otpuštanja u privatnom sektoru), kao i povećanja neizvesnosti. Devizni kurs je tokom perioda glavnog uticaja globalne krize depresirao prema evru - nominalna depresijacija za oko 6\% (februar 2010. prema septembru 2009), realna depresijacija na kraju 2009. u odnosu na septembar 2008. iznosila je oko $14 \%$.

Monetarna politika se već krajem 2008. godine usmerila na ograničavanje nagle depresijacije dinara restriktivnom monetarnom politikom i to, $u$ prvo vreme, podizanjem kamatne stope. Ova mera je trebalo da ima efekat i na ograničavanje inflacije, čije je kretanje na početku prelivanja krize, krajem
2008. godine i početkom 2009. godine, još uvek bilo zabrinjavajuće, mada se stopa inflacije stabilizovala do kraja 2009. godine, da bi problem inflacije postao aktuelan ponovo sa oporavkom, tokom 2010. godine, što se uklapa u činjenicu da je stopa inflacije indikator koji kasni. Depresijacija dinara delovala je stimulativno na privrednu aktivnost, prvenstveno na podsticanje izvoza i ograničavanje uvoza, ali se zbog straha od inflacije insistiralo na ograničenoj depresijaciji koja je podrazumevala monetarnu kontrakciju.

Pored sprečavanja značajnije depresijacije kursa, monetarne vlasti su se suočile i sa problemom smanjene likvidnosti privrede. Međutim, ovaj problem nije primarno rešavan od strane Narodne banke Srbije (NBS) zbog inflatornih pritisaka i nemogućnosti obaranja kamatne stope, već je to prepušteno fiskalnoj politici. Monetarna politika se nije koristila u kontraciklične svrhe, već primarno za održanje makroekonomske stabilnosti - cenovne stabilnosti i za smanjenje fluktuacija deviznog kursa. Takav izbor od strane monetarnih vlasti ne iznenađuje ako se u obzir uzmu fiskalna ograničenja, kao i drugi faktori vezani za dotadašnji karakter privrednog rasta u Srbiji. Monetarni odgovor bio je u mnogome uslovljen fiskalnom neravnotežom i nesposobnošću da se reše fiskalni debalansi koji su u Srbiji postojali i pre otpočinjanja krize, a koji su imali političko ishodište. Zbog toga je monetarna politika ostala garant za makrokeonomsku stabilnost, što nas navodi na zaključak o nedovoljnoj koordinaciji između monetarne i fisklane politike, koje su sprovođene radi prevazilaženja efekata globalne ekonomske krize.

\section{FISKALNA POLITIKA - NAČIN ZA PREVAZILAŽENJE RECESIONIH PRITISAKA ILI IZVOR POLITIČKIH MANIPULACIJA}

Srbija je $\mathrm{u}$ period globalne ekonomske krize ušla sa otvorenim problemom javnih finansija - deficita državnog budžeta koji je bio posledica ekspanzivne fiskalne politike u periodu 2006-2008, a što se upravo podudarilo sa politički motivisanim zloupotrebama ekonomske politike i usporavanjem ekonomskih reformi u Srbiji. Sa zaokretom $u$ vođenju fiskalne 
politike upravo se poklapaju izborni ciklusi koji su realizovani u periodu pre otpočinjanja krize u Srbiji. Kao posebno važne godine (u kontekstu predizborne ekspanzivne fiskalne politike) izdvajaju se 2006, 2007. i 2008. godina, dakle, tri godine neposredno pred otpočinjanje globalne ekonomske krize.

Iz budžetskog suficita ostvarenog u 2005. godini od oko $1 \%$ BDP-a, prešlo se u deficit od oko $2 \%$ BDP-a (2006. i 2007.), odnosno, 2,6\% BDP-a (2008.). U ovako nepovoljnim uslovima otpočelo je delovanje globalne ekonomske krize, kada se sa pravom moglo pretpostaviti da će doći do pada BDP-a, što bi, ukoliko se ne preduzmu mere fiskalne štednje ili rasta poreza, dovelo do još većeg deficita državnog budžeta. Istovremeno, moglo se pretpostaviti da će se restriktivna fiskalna politika teško realizovati $\mathrm{u}$ uslovima krize kada je neizbežan pad poreskih prihoda zbog usporavanja privredne aktivnosti, a istovremeno se može pretpostaviti još veći pritisak da se povećaju budžetski rashodi kako bi država podstakla privrednu aktivnost, kroz različite oblike stimulacije privrede i potrošača. Povećanju budžetskih rashoda doprinosiće i pogoršanje socijalnog položaja stanovništva i neizbežan rast nezaposlenosti. Zbog toga se stanje deficita pogoršavalo, tako da je tokom krizne 2009. godine konsolidovani budžetski deficit iznosio 4,5\% BDP-a, a zbog izuzetne ekspanzivnosti fiskalne politike i nedovoljnog ekonomskog oporavka on je u postkriznim godinama ostao veoma visok $(4,7 \%$ u 2010. i 5,0\% u 2011). U prethodnoj, 2012. godini, koja je, takođe, bila i predizborna i godina promene vlasti (kreatora ekonomske politike), kulminirao je problem deficita koji je u poslednjem kvartalu iznosio čak 7,3\% BDP-a (Tabela 1), namećući se kao prvo i najvažnije pitanje kreatorima ekonomske politike.

Politička makroekonomija $\mathrm{u}$ domenu zloupotrebe fiskalne politike u političke - izborne svrhe (budžetski politički ciklusi) razlikuje nekoliko modaliteta, na osnovu kojih su razvijeni i odgovarajući modeli budžetskih ciklusa (Cukierman \& Meltzer, 1986; Rogoff \& Sibert, 1988; Rogoff, 1990; Drazen, 2000). Među njima su: modeli bazirani na fiskalnoj iluziji, modeli u kojima je budžetski deficit strateška varijbla, modeli međugeneracijske preraspodele, modeli distribucionog konflikta, modeli geografski disperzovanih interesa i modeli budžetskih institucija (231; Jakšić i Praščević,
2010, 279-290). Ključni mehanizmi fiskalne zloupotrebe izloženi $u$ ovim modelima mogu se primeniti na fiskalnu politiku vođenu u Srbiji pred, tokom i nakon globalne ekonomske krize.

Modeli bazirani na fiskalnoj iluziji podrzumevaju da glasače karakteriše "fiskalna iluzija", odnosno, da oni ne razumeju intertemporalno budžetsko ograničenje precenjujući koristi od trenutnog povećanja izdataka i podcenjujući trenutne i buduće poreske obaveze. Zbog toga glasači ne kažnjavaju oportunistički motivisanu politiku generisanja budžetskog deficita. U Srbiji je ta forma fiskalne iluzije bila dopunjena još jednim faktorom - prihodima od privatizacije koji su se mogli korisititi i u oportunističke političke svrhe. Takav je primer bio Nacionalni investicioni plan - NIP (20062011) koji je definisao veliki broj prioriteta u oblasti izgradnje infrastrukture, regionalnog razvoja, ali i školstva, zdravstva i kulture. Umesto promišljenog i planskog investiranja države u četiri sektora, što bi u srednjem roku dovelo do rasta proizvodnih potencijala zemlje, a time i budućih budžetskih prihoda, ovi efekti su izostali.

Fiskalna politika u Srbiji se u predizbornim periodima uklapa i u modele racionalnih budžetskih ciklusa, koji podrazumevaju da su glasači fiskalno konzervativni, a bivaju obmanuti kroz promenu strukture državnih izdataka u korist onih koji su brzo i lako "vidljivi". Tako se $u$ izbornim godinama može uočiti značajan rast tzv. diskrecionih javnih rashoda - javnih investicija, subvencija, budžetskih pozajmica i sl. Ovi rashodi obezbeđuju "kompetentnost" kreatorima ekonomske politike kojom se obmanjuju glasači.

Mere fiskalne politike sa značajnim političkim uporištem u periodu pred ekonomsku krizu (20062008) bile su:

- izrazit rast plata $\mathrm{u}$ javnom sektoru tokom predizborne 2006. godine, koji se nastavio i tokom 2007. godine, po osnovu realizacije ugovora sindikata i Vlade u predizbornom periodu tokom 2006. godine;

- pokretanje Nacionalnog investicionog plana 2006. godine;

- programi subvencija preduzećima (malim, srednjim i onim u restrkturiranju) tokom 2006. godine; 
- smanjenje stope poreza na zarade i uvođenje neoporezivog dela zarade tokom 2007. godine;

- smanjenje nekih od poreskih stopa - poreza na prenos apsolutnih prava, PDV-a za određene proizvode, potpuno oslobađanje od plaćanja PDV-a na kupovinu prvog stana tokom 2007. godine (Praščević, 2012b, 147).

Ovakvo ponašanje fiskalnih vlasti u predkriznom periodu ograničilo je mogućnost njenog korišćenja u podsticanju privredne aktivnosti u Srbiji tokom krize. Revidiranjem sporazuma sa MMF-om u maju 2009. godine povećan je dozvoljeni deficit na 4,5\% BDP-a, što je bilo $\mathrm{u}$ skladu sa promenama u pristupu MMF-a usled drastične privredne kontrakcije, ali je bilo i izraz realnosti koja je onemogućavala da se sprovedu značajnije mere štednje jer bi doprinele još većoj recesiji.

I pored ograničenja nametnutih prošlim kretanjima zbog kojih se odmah nakon formiranja prethodne vlade (u julu 2008.) pojavila potreba za fiskalnom konsolidacijom, moguće je uočiti nastavak politički motivisane fiskalne i šire ekonomske politike $u$ borbi protiv recesije, vođene od strane vlade (2008-2012). Objektivni razlog za to se može naći u činjenici da je prethodna vlada sebe, makar u prvom periodu nazivala "socijalno odgovornom vladom", čiji su ključni ciljevi pored pridruživanja EU, bili i brži privredni rast, smanjenje stope nezaposlenosti, kao i poboljšanje životnog standarda stanovništva, smanjenje siromaštva i pravednija raspodela troškova ekonomskih reformi i tranzicije. Faktori koji se odnose na sastav koalicione vlade, koja je okupljala patrije različite političke orijentacije (sa različitim ekonomskim ciljevima), kao i koalicioni sporazum o načinu funkcionisanja vlade (podela ministarskih resora između koalicionih partnera) i vladajuće većine, upravljanje javnim preduzećima i slično, otežali su značajno realizaciju fiskalne stabilizacije. Vrlo brzo je došlo do problema poznatog u modelima političke makroekonomije kao distribucioni konflikt, kada koalicioni partneri u vladi, koji formulišu fiskalnu politiku, ne žele da na sebe, odnosno, na svoje birače prevale teret fiskalne stabilizacije, već taj teret pokušavaju da prebace na druge koalicione partnere (Alesina \& Drazen, 1991, 1170).
Preduzete antirecesione mere države (podrška finansijskom sektoru, osiguranje depozita, subvencionisanje kamate za određene kredite, obezbeđenje kredita malim i srednjim preduzećima, podsticanje javnih investicija) imale su pozitivne efekte (Praščević, 2012b, 152), mada je tokom 2009. godine do izražaja došao i efekat istiskivanja kao posledica visokog deficita državnog budžeta, s jedne strane, i velikog kreditnog rizika privrede, zbog čega su banke preferirale ulaganje $\mathrm{u}$ državne obveznice, a ne $u$ privredu. Tome je doprinelo i to što je fiskalni deficit u Srbiji u 2009. godini finansiran primarno zaduživanjem, jer su izvori iz privatizacionih prihoda presušili. Važna podrška ekonomskoj politici u 2009. godini bio je sklopljen aranžman sa MMF-om, koji je predvideo finansijsku podršku od 2,9 mlrd. evra. Programom je predviđeno smanjenje potrošnje javnog i privatnog sektora, s obzirom da se više ne može računati na značajne prilive kapitala iz inostranstva. Programom je bilo predviđeno zamrzavanje plata u javnom sektoru i penzija, koje je ostalo prisutno i tokom 2010. godine, kao i smanjenje diskrecione potrošnje za dobra i usluge, subvencije, kreditiranje svih nivoa vlasti. Međutim, u državnim rashodima najveće smanjenje beležili su kapitalni izdaci, što ukazuje na značajna recesiona kretanja.

U 2010. godini zabeležen je slab oporavak (rast BDP-a od 1,0\%), koji je nastavljen i 2011. godine (rast BDP-a od $1,6 \%$ ), što je značajno manje u odnosu na stope koje su postojale pre krize. Tokom 2010. godine došlo je do oporavka agregatne tražnje i to značajnijeg rasta izvozne tražnje što je jednostavno objasniti činjenicom da su plate i penzije ostale zamrznute, kao i da se aktuelizovao problem visoke nezaposelnosti, zbog čega nije bio moguć značajniji rast domaće tražnje. Kretanja na tržištu rada u postkriznom periodu (2010, 2011. i 2012. godine), međutim, nisu bila ohrabrujuća (nezaposlenost je nastavila da raste, a zaposlenost da opada - Tabela 3). Treba istaći da se broj lica koja su ostala bez posla nije odnosio na javni sektor, jer je zbog globalne ekonomske krize i negativnih ekonomskih kretanja u zemlji, odložena neophodna reforma javnog sektora koja će neminovno podrazumevati otpuštanje radnika u ovom sektoru i rast nezaposlenosti i po ovom osnovu. Ipak, kretanja na tržištu rada su izuzetno nepovoljna - za četiri godine (od 2008.) 
došlo je do pada zaposlenosti za oko $10 \%$, što dodatno komplikuje ekonomsku situaciju u Srbiji i govori o teškom ekonomskom položaju većeg dela stanovništva Srbije.

Tabela 3 Stopa zaposlenosti i nezaposlenosti u Srbiji, 2004-2012

\begin{tabular}{lccc}
\hline & $\begin{array}{c}\text { Stopa } \\
\text { zaposlenosti } \\
\text { (15-64 god.) }\end{array}$ & $\begin{array}{c}\text { Ukupan broj } \\
\text { zaposlenih } \\
\text { (15-64 god.) }\end{array}$ & $\begin{array}{c}\text { Stopa neza- } \\
\text { poslenosti } \\
\text { (15-64 god.) }\end{array}$ \\
\hline Okt. 2004 & 53,4 & 2.735 .977 & 19,5 \\
Okt. 2005 & 51,0 & 2.574 .139 & 21,8 \\
Okt. 2006 & 49,8 & 2.516 .794 & 21,6 \\
Okt. 2007 & 51,5 & 2.525 .570 & 18,8 \\
Okt. 2008 & 53,3 & 2.646 .215 & 14,7 \\
Okt. 2009 & 50,0 & 2.450 .643 & 17,4 \\
Okt. 2010 & 47,1 & 2.269 .565 & 20,0 \\
Okt. 2011 & 45,3 & 2.141 .920 & 24,4 \\
Apr. 2012 & 44,2 & 2.083 .604 & 26,1 \\
\hline
\end{tabular}

Izvor: Republički zavod za statistuku. Anketa o radnoj snazi.

Oporavak srpske privrede bio je veoma slab, a do izražaja su došli problemi u vezi sa rastućom inflacijom, budžetskim deficitom i javnim dugom, tako da se monetarna politika u pojedinim periodima opredeljivala za izrazitu restriktivnost, $\mathrm{u}$ obuzdavanju inflacije. Devizni kurs je beležio značajnije fluktuacije koje su, s jedne strane, ukazivale na potrebu za daljom depresijacijom dinara, ali su sve glasniji postali i zahtevi da se pređe na fiksni devizni kurs, što bi bilo posebno teško realizovati u situaciji veoma nepovoljnih fiskalnih tokova koji su prisutni poslednjih godina $\mathrm{u}$ Srbiji.

Fiskalna kretanja u Srbiji dokazuju da su vlade $\mathrm{u}$ nestabilnim i polarizovanim političkim sistemima, kakav je prisutan u Srbiji, sklone visokim deficitima, jer je deficit pozitivno korelisan sa stepenom političke polarizacije između potencijalnih vlada, sa dužinom mandata vlade i sa izgledima da vlada ne bude ponovo izabrana (Persson \& Svensson, 1989; Alesina \& Tabellini, 1990). Nesumnjiva politička polarizacija dovela je u Srbiji do situacije $u$ kojoj je budžetski deficit postao strateška varijabla, kojom trenutna vlada utiče na fiskalnu politiku buduće vlade, jer se manipulisanjem trenutnom fiskalnom politikom utiče na izbor fiskalne politike koju će realizovati budući kreatori ekonomske politike, iako će oni možda imati drugačije preferencije. Primer ovakve fiskalne politike je upravo politika vođena pred i nakon poslednjih izbora (parlamentarnih i predsedničkih, maja 2012. godine).

\section{EKONOMSKA POLITIKA U \\ PREDIZBORNOM PERIODU I NOVA EKONOMSKA POLITIKA}

Politička nestabilnost koja se u zemlji pojačavala od sredine 2011. godine (značajnije nesuglasice između koalcionih partnera $\mathrm{u}$ vladi i pritisak opozicionih partija na raspisivanje izbora), značajno je uticala i na ekonomska kretanja. Ove tenzije su okončane redovnim parlamentarnim (republičkim i lokalnim) i prevremenim predsedničkim izborima, održanim početkom maja 2012. godine. Zbog toga je prva polovina 2012. godine protekla u predizbornim aktivnostima, a zbog promene vlasti kako na republičkom nivou (vlade i predsednika Republike), tako i na lokanim nivoima, druga polovina godine je uglavnom bila posvećena formiranju i konsolidovanju vlasti, a na nivou kreatora ekonomske politike bile su najavljene značajnije promene $u$ odnosu na dotadašnju ekonomsku politiku. Uzimajući u obzir ranija iskustva sa ekonomskim kretanjima u predizbornom i postizbornom periodu u Srbiji, ne čudi što su ona tokom 2012. godine bila veoma nepovoljna. Tome treba dodati da su i ekonomska kretanja na globalnom planu, a za Srbiju naročito važna kretanja u evrozoni, postala nepovoljna (evrozona je ponovo ušla u recesiju).

Posebno važnu ulogu, kao što je to zabeleženo i tokom ranijih izbora (na različitim nivoima), imala je fiskalna politika. Fiskalna politika je po dva osnova ostala okosnica ukupne ekonomske politike:

- usled neznatnog privrednog rasta i dalje je bila prisutna potreba da se fiskalnom politikom države utiče na podsticanje privredne aktivnosti; i 
- fisklana politika je u predizbornom periodu ostala najvažniji instrument mogućeg uticaja na poboljšanje ekonomske pozicije glasača "kupovinu" glasova.

Fiskalne tokove u Srbiji treba posmatrati i u kontekstu privremenog obustavljanja saradnje sa MMF-om (nemogućnosti sklapanja druge revizije aranžmana iz predostržnosti postignutog septembra 2011. godine $u$ vrednosti od 1,1 milijardi evra) do koje je došlo u martu 2012. godine, zbog neslaganja sa kreatorima ekonomske politike u vezi sa obuzdavanjem budžetskog deficita i emisijom duga. Za razliku od uspešne prve revizije iz novembra 2011. godine, koja je predviđala da će ciljani deficit budžeta u 2012. biti 4,25\% BDP-a, uz očekivanje da će privredni rast 2012. godine biti 1,5\%, veoma nepovoljna ekonomska kretanja su ukazivala da se planirani privredni rast neće ostvariti, kao i da će deficit biti značajnije veći. Zbog toga su od strane MMF-a postavljeni sledeći uslovi: zahtev za rebalansom budžeta, zahtev za smanjenjem dodatne potrošnje i emisije duga, usvajanje srednjoročnog fiskalnog programa i ubrzanje strukturnih reformi. S obzirom na nesposobnost kreatora ekonomske politike da $u$ predizbornom periodu (u proleće 2012. godine) primene mere značajnije fiskalne restrikcije, ne čudi privremeno obustavljanje saradnje i MMF-ova namera da o nastavku aranžmana razgovara sa novom vladom.

Prema makroekonomskim pokazateljima, 2011. godina je bila prelomna za negativna kretanja koja su kasnije kulminirala tokom 2012. godine. Veliki deo odgovornosti za to snose kretaori ekonomske politike. Iako je deklarativno utvrđeno opredeljenje za novi model rasta baziran na izvoznoj tražnji, a time i na značajnijoj proizvodnji i ulaganjima u sektore koji proizvode razmenljiva dobra, realizacija toga je izostala. Umesto toga, tokom 2011. godine došlo je do značajnog pada neto izvoza, koji se delimično dugovao i realnoj apresijaciji dinara u 2011. godini (usled visokog priliva inostranog kapitala koji je, međutim, bio jednokratan), ali i smanjenju proizvodnje i izvoza čelika sa pogoršanjem poslovanja u kompaniji US Steel Serbia. Deficit tekućeg bilansa je 2011. godine zabeležio značajan rast (na 9,2\% BDP-a - primarno zbog smanjenja priliva tekućih transakcija), što će se zbog nepostojanja značajnijih priliva kapitala iz inostranstva tokom 2012. godine nastaviti daljim porastom deficita i problemom održavanja vrednosti dinara, koji će neminovno beležiti depresijaciju.

Međutim, tokom 2011. godine beležena su povoljna kretanja $\mathrm{u}$ visini stranih direktnih investicija (za dokapitalizaciju banaka, ulaganje u trgovinu na malo, građevinarstvo), portfolio investicija i ostalih investija. Ovaj rast je, međutim, bio jednokratan i ograničen i nije nastavljen u 2012. godini. Vrednost spoljnog duga je u 2011. godini nastavila da u apsolutnom iznosu ( $u$ milionima evra) raste dok je zbog realne apresijacije dinara smanjen odnos duga prema BDP-u, $u$ odnosu na 2010. godinu. Do rasta zaduženosti je došlo usled povećanja zaduživanja javnog sektora $\mathrm{u}$ inostranstvu (uz blago smanjenje zaduživanja privatnog sektora).

Inflacija je tokom 2011. godine stavljena pod kontrolu $(7 \%)$, iako je do maja beležila tendenciju rasta iz prethodne, 2010. godine (u maju je međugodišnja stopa inflacije bila čak 17,9\%), nakon čega je došlo do njene stagnacije i pada. Što se tiče deviznog kursa, nakon njegove apresijacije $\mathrm{u}$ prvoj polovini godine, $\mathrm{u}$ drugoj polovini godine došlo je do njegove nominalne depresijacije koja je nastavljena i u 2012. godini, da bi tek $\mathrm{u}$ poslednjem kvartalu 2012. godine ona bila zaustavljena, a prosečni kurs dinara vraćen na nivo iz drugog kvartala 2012. godine.

Za ekonomsku politiku vođenu $\mathrm{u}$ predizbornom periodu, odnosno, poslednjim mesecima prethodne vlade može se reći da je bila nesistematična i opredeljena kratkoročnim ciljevima. Kreatori ekonomske politike i ovog puta su ponovili značajnu fiskalnu ekspanziju koja je bila prisutna i u svim prethodnim predizbornim periodima (deficit je $\mathrm{u}$ prvoj polovini 2012. bio čak 7\% BDP-a). Bez obzira na takvu ekspanziju, izostali su kratkoročni efekti na rast privredne aktivnosti. Upravo suprotno, privredna aktivnost je opadala, realni međugodišnji pad BDP-a u drugom kvartalu 2012. godine je bio oko 0,6\%, da bi se pad tokom trećeg kvartala zbog posledica nepovoljnih vremenskih uslova (suše) povećao na 2,2\% BDP-a (na međugodišnjem nivou).

Pozitivni efekti na ekonomski rast su izostali, čak i u kratkom roku, ali nisu izostali efekti dinamiziranja agregatne tražnje na rast inflacije i slabljenje domaće valute. U modelima političke makroekonomije poznati su ovi efekti (u okviru oportunističkih modela 
političkih ciklusa), ali se uspešnost korišćenja povećane državne potrošnje zasniva na dobrom "tajmingu", koji je u ovom slučaju izostao. Naime, privreda Srbije je već ušla u recesiju, a izbori su morali da budu održani (određen je prema Zakonu njihov poslednji termin), što znači da kreatori ekonomske politike nisu imali mnogo izbora u vezi sa "tajmingom". U međuvremenu su se desile i neke nepredviđene okolnosti na koje se nije moglo uticati (loši meteorološki uslovi u februaru 2012. godine, koji su smanjili privrednu aktivnost, negativna ekonomska kretanja u evro zoni i komplikovanje slučaja železare US Steel Srbija, za koju se još u decembru 2011. godine nagađalo da će biti zatvorena, umesto čega je država "kupila" železaru za simboličnu cenu od $1 \$$, sa nejasnom vizijom budućnosti, ali sa ciljem da se izbegne da oko 4.500 radnika ostane bez posla u predizbornom periodu).

Ekonomska kretanja u Srbiji su bila u toj meri loša da ni značajna državna potrošnja nije mogla da ih preokrene (iako je u aprilu i delimično u maju došlo do uzleta industrijske proizvodnje), jer je izostao rast neto izvoza i investicija. To navodi na činjenicu da je dosadašnji pogrešan model rasta, ali i oporavka u Srbiji doživeo potpuni krah, što otvara mogućnost da će novi kretaori ekonomske politike od njega odustati.

Da je ekonomska politika u prevazilaženju uticaja globalne ekonomske krize (2008-2009) bila u suštini pogrešna govori podatak i da privredna aktivnost još uvek nije dostigla nivo iz proleća 2008. godine (pre delovanja globalne krize), već je $\mathrm{u}$ drugom kvartalu 2012. godine bila niža za 3\% u odnosu na isti period 2008. Struktura upotrebe BDP-a u predizbornom periodu u potpunosti odgovara populističkoj i politički motivisanoj ekonomskoj politici:

- značajan rast državne potrošnje (za kupovinu roba i usluga, rast plata) - doprineo rastu BDP-a;

- rast privatne potrošnje - poticao od realnog rasta prosečne zarade i realni rast mase penzija doprineo rastu BDP-a;

- pad investicija - doprineo padu BDP-a;

- pad neto izvoza - doprineo padu BDP-a.

Nekontrolisan rast državne potrošnje u 2012. godini nametnuo je probleme javnog i spoljnog duga Srbije. Ukupni javni dug je na kraju drugog kvartala iznosio 56\% BDP-a, da bi na kraju godine iznosio čak 59\% BDP-a (zaduživanja države emisijom evroobveznica), čime je značajno nadmašio zahtevanih $45 \%$ BDP-a. Pored zaduživanja u inostranstvu, država se zaduživala i u zemlji (emisija trezorskih zapisa). Međutim, visina spoljnog duga ukazuje da će on na kraju 2012. godine preći $80 \%$ BDP-a, sa visokim troškovima njegovog vraćanja u budućnosti. U cilju otklanjanja pretnje spoljnoj likvidnosti zemlje i s obzirom da je tokom 2012. godine došlo do smanjenja deviznih rezervi, neophodne su mere ekonomske politike na smanjenju deficita tekućeg platnog bilansa, odnosno, na povećanju izvoza, ograničavanju domaće tražnje i prihvatanju politike deviznog kursa koji bi se bazirao na održivom deviznom kursu (odustajanje od precenjenog dinara i veštačkog održanja kursa po cenu trošenja deviznih rezervi).

Ekonomska politika nove vlade se suočava sa značajnim ograničenjima - dinamiziranje domaće tražnje je dostiglo svoj vrhunac i na njega se više ne može računati, podsticanje privredne aktivnosti merama ekonomske politike je veoma ograničeno i može se odnositi na eventualno korišćenje politike deviznog kursa, prvenstveno njegovu depresijacije u cilju poboljšanja cenovne konkurentnosti i izvoza privrede Srbije. To dovodi do zaključka da su neophodne reforme ekonomskog sistema Srbije i poboljšanje poslovanja u Srbiji. U tom kontekstu su najavljene mere za olakšanje procedura poslovanja, procedura dobijanja različitih dozvola (uključujući i građevinske dozvole), poreske procedure i što je najvažnije - otklanjanje svih oblika koruptivnog ponašanja u poslovanju.

Kao prvi zadatak novoj vladi nametnula se konsolidacija javnih finansija, što nije neuobičajeno kako za ranija iskustva u vezi sa predizbornim fiskalnim kretanjima u Srbiji, tako i za ono čemu nas uče modeli budžetskih političkih ciklusa. Ovako visok deficit i rast zaduženosti, u potpunosti odgovaraju postavci da se u situaciji u kojoj se kreatori ekonomske politike suočavaju sa mogućnošću gubitka vlasti oni opredeljuju za izrazitu ekspanzivnost ekonomske politike. Pored budžetskog deficita, kao izrazit problem je nametnuta i visoka inflacija, kao i depresijacija dinara. Ovaj treći problem - pad vrednosti dinara (nominalni i realni), prvi je otklonjen i to najpre nominalnom, a 
zatim i značajnom realnom apresijacijom kursa (usled visoke stope inflacije, a relativno stabilnog nominalnog deviznog kursa). Rešavanje problema inflacije i depresijacije, pored fiskalne restrikcije, zahtevalo je i restriktivnu monetarnu politiku, sa kojom je Narodna banka Srbije nastavila i pod novim guvernerom. Među ovim merama je svakako bio dalji rast referentne kamatne stope, povećanje dinarskog dela deviznih obaveznih rezervi i prelazak na standardne repo operacije.

Fiskalna politika će i u narednom periodu biti okosnica ekonomske politike, slično kao što je to bila i u slučaju prethodne vlade. U domenu javnih finansija, nova vlada je preduzela korake na ograničavanju državne potrošnje. Novi kreatori ekonomske politike su, makar deklarativno, na stanovištu da se budući oporavak privredne aktivnosti i ekonomski rast neće zasnivati na nerealnom rastu domaće tražnje, primarno državne potrošnje. Ne sme se, međutim, zaboraviti da je i prethodna vlada 2011. godine usvojila "novi model rasta" za koga se upravo smatralo da će biti kraj dotadašnje prakse rasta na osnovu domaće tražnje. Iako deklarativno usvojen, ovaj model nije $u$ praksi zaživeo, niti je bio podržan odgovarajućim merama ekonomske politike.

\section{ZAKLJUČAK}

U radu je pokazano da je ekonomska politika za prevazilaženje efekata globalne ekonomske krize na privredu Srbije imala pomešane efekte. Kratkoročno, pozitivni efekti u vidu blagog oporavka od 2010. godine nisu izostali, ali je u srednjem roku ekonomska politika doživela neuspeh. Tome su svakako doprinela značajna ograničenja sa kojima se u period globalne krize ušlo, a koja su se odnosila na nasleđe visokog budžetskog deficita i loše stanje javnih finansija, kao i na pogrešan model rasta zasnovan na rastu domaće tražnje. Ovi su se problemi dodatno produbili neophodnošću značajnije intervencije države $u$ ekonomiji i fiskalne ekspanzije. Fiskalna stimulacija, kao neophodan način za podsticanje privredne aktivnosti $u$ periodu ekonomske krize, u Srbiji je bila vezana i za nastavak oportunistički i stranački motivisane zloupotrebe ekonomske politike. U radu je pokazano da je fiskalna politika u Srbiji u čitavom periodu pred, tokom i nakon delovanja globalne ekonomske krize ostala pod značajnim uticajem političkih faktora, koji su uslovili njenu zloupotrebu na načine koji su poznati $\mathrm{u}$ literaturi političke makroekonomije. Istovremeno, monetarna politika je prvenstveno bila $u$ funkciji održavanja cenovne stabilnosti, često pokušavajući da ograniči negativne efekte preduzetih fiskalnih mera. Zbog toga se može govoriti o odsustvu koordinacije monetarne i fiskalne politike. Pogoršanje ekonomskih kretanja posebno je očigledno u poslednjim mesecima prethodne vlade, neposredno pred i naročito nakon izbora.

Politička manipulacija ekonomske politike prisutna $\mathrm{u}$ ranijim godinama ostavila je loše nasleđe novim kreatorima ekonomske politike, uslovljajvajući neke od njihovih prvih poteza. Tako im je nametnuta neophodnost fiskalne konsolidacije, kako to navode i modeli budžetskih političkih ciklusa. Uzimajući u obzir sva ograničenja do nedavno korišćenog modela rasta - baziranog na domaćoj tražnji, kreatorima ekonomske politike ne ostaju nikakve mogućnosti za njegovu dalju primenu, već se moraju usredsrediti na pronalaženje novih izvora rasta - prvenstveno izvoza, za koji je neophodno pokretanje proizvodnje, ali su od podjednakog značaja strukturne reforme i stalno odlagana reforma javnog sektora. To daje izvestan optimizam da se u budućnosti neće ponavljati greške namerno korišćenje instrumenata ekonomske politike $\mathrm{u}$ političke svrhe, jer su mogućnosti za to gotovo potpuno isrpljene (izuzetno visok fiskalni deficit, visok javni dug, problem obuzdavanja inflacije).

\section{ZAHVALNICA}

Ovaj rad deo je Projekta osnovnih istraživanja (br. 179065), koji finansira Ministarstvo nauke Republike Srbije.

\section{REFERENCE}

Alesina, A. (1987). Macroeconomic Policy in a Two-Party System as a Repeated Game. Quarterly Journal of Economics, 102(3), 651-678. 
Alesina, A., \& Tabellini, G. (1990). A Positive Deficits of Fiscal Deficits and Government Debt. Review of Economic Studies, $57,403-414$

Alesina, A., \& Drazen, A. (1991). Why Are Stabilizations Delayed? American Economic Review, 81(5), 1170-1188.

Cukierman, A., \& Meltzer, A. (1986). A Positive Theory of Discretionary Policy, the Cost of Democratic Government, and the Benefits of a Constitution. Economic Inquiry, 24, 367388.

Drazen, A. (2000). The Political Cycles After 25 Years. NBER Macroeconomic Annual, Cambridge. Mass: MIT Press.

Hibbs, D. (1977). Political Parties and Macroeconomic Policy. American Political Science Review, 71 (4), 1467-1487.

Jakšić, M., i Praščević, A. (2010). Politička makroekonomija. Beograd: Ekonomski fakultet Univerziteta u Beogradu.

Nordhaus, W. (1975). The Political Business Cycle. Review of Economic Studies, 42(2), 169-190.

Persson, T., \& Svensson, L. (1989). Why a Stubborn Conservative Would Run a Deficit: Policy With Time-Inconsistent Preferences. Quarterly Journal of Economics, 104, 325 - 345.

Persson, T., \& Tabellini, G. (1990). Macroeconomic Policy, Credibility, and Politics. Chur, Switzerland: Harwood Academic Publishers.

Praščević, A. (2008a). Poslowni ciklusi u makroekonomskoj teroiji $i$ politici, Beograd: Ekonomski fakultet Univerziteta $\mathrm{u}$ Beogradu.

Praščević, A. (2008b). Politički faktori makroekonomske nestabilnosti u Srbiji. U M. Zec, i B. Cerović (Urednici), Kuda ide Srbija? - Ostvarenja $i$ dometi reformi (str. 43-69). Beograd: Naučno društvo ekonomista i Ekonomski fakultet Univerziteta u Beogradu.

Praščević, A. (2010). Odnos javnost - elita i brzina reformskih procesa u Srbiji: Zašto su reforme u Srbiji usporene? U M. Arandarenko, A. Praščević, i S. Cvejić (Urednici), Ekonomsko - socijalna struktura Srbije: Učinak prve decenije tranzicije (str.
87-105). Beograd: Naučno društvo ekonomista i Ekonomski fakultet Univerziteta u Beogradu.

Praščević, A. (2012a). Development of Modern Macroeconomics in the Context of Global Economic Crisis. In B. Cerović, M. Jakšić, Z. Mladenović, \& A. Praščević (Eds.), From Global Crisis to Economic Growth. Which Way to Take?, (pp. 603-629). Belgrade: Faculty of Economics of the University of Belgrade.

Praščević, A. (2012b). The Role of Government in Overcoming the Effects of Global Economic Crisis in Serbia - Obstacles from the Past. Montenegrin Journal of Economics, 8(1), 137-155.

Radisavljević, G. (2010), Lična potrošnja u Republici Srbiji, 20002009, Studije i analize. Beograd, Republika Srbija: Republički zavod za statistiku.

Rogoff, K., \& Sibert, A. (1988). Elections and Macroeconomic Policy Cycles. Review of Economic Studies, 55, 1-16.

Rogoff, K. (1990). Equilibrium political budget cycles. American Economic Review, 80, 21-36.

Spilimbergo, A., Symansky, S., Blancard, O., \& Cottarelli, C. (2008). Fiscal Policy for the Crisis. IMF Staff Position Note. Retrived July 7, 2010, from http://www.imf.org/external/ pubs/ft/spn/2008/spn0801.pdf

Stamenković, S., Kovačević, M., Vučković, V., Nikolić, I. i Bušatlija, M. (2009). Ekonomska politika u 2010. godini: ka novom modelu ravnoteže. U B. Zivković, i S. Stamenković (Urednici), Ekonomska politika Srbije u 2010. g. - Ka novom modelu makroekonomske stabilnosti (str. 15-69). Beograd: Naučno društvo ekonomista i Ekonomski fakultet Univerziteta u Beogradu.

Narodna banka Srbije. Statistika - Osnowni makroekonomski indikatori. Retrived March 1, 2013, from http://www.nbs.rs.

Narodna banka Srbije. Statistika - Platni bilans RS. Retrived March 1, 2013, from http://www.nbs.rs.

Republički zavod za statistiku. Anketa o radnoj snazi. Retrived Febuary 7, 2013, from http://webrzs.stat.gov.rs.

Primljeno 11. marta 2013, nakon revizije, prihvaćeno za publikovanje 19. aprila 2013.

Aleksandra Praščević je vanredni profesor na Ekonomskom fakultetu Univerziteta u Beogradu, na nastavnim predmetima: Osnovi makroekonomije, Makroekonomska analiza i Istorija ekonomije. Oblast njenog naučnog interesovanja je politička makroekonomija, naročito, politički generisane ciklične makroekonomske fluktuacije. 


\title{
ACHIEVEMENTS OF ECONOMIC POLICY IN OVERCOMING THE EFFECTS OF THE GLOBAL ECONOMIC CRISIS ON SERBIAN ECONOMY
}

\author{
Aleksandra Prascevic \\ Faculty of Economics, University of Belgrade, Belgrade, Serbia
}

\begin{abstract}
The paper deals with the extent to which the economic policy in Serbia has managed to respond to the economic problems imposed by the global economic crisis and how the restrictions in the form of political instability and political influence, present also before the crisis, influenced the economic policy formulated to combat the crisis. Globally, the economic crisis has resulted in the fact that instead of the rules in economic policy making, with the key objective of maintaining price stability, now discretion and fiscal policy are being promoted, with the aim of overcoming the problem of unemployment. Significant use of discretion in economic policy generally imposes the problem of competence and possible political motives of the economic policy makers. It is the limitations of underdeveloped institutions and a wrong model of growth that have contributed to the fact that the results of economic policy in Serbia have not been significant. Serbia is facing the negative consequences of the measures implemented in the form of high budget deficits, public debt and inflation, while the effects on economic activity and employment have failed, causing present choice between rules and discretion.
\end{abstract}

Keywords: global economic crisis, economic policy, political macroeconomics

JEL Classification: E60, E62 